\title{
Regime-Switching in Exchange Rate Policy and Balance Sheet Effects
}

\author{
(c) Norbert Fiess* and Rashmi Shankar\#
}

\begin{abstract}
It is well accepted that exchange rate policy in many emerging markets has been characterized by shifts between a stronger and weaker commitment to peg. This raises the following questions, which we address in our paper: Does intervention policy exhibit clearly defined and periodic shifts? What drives this policy variability? We identify clearly defined switches between high and low intervention in all the countries in our sample. We also find strong evidence that balance sheet effects, proxied by the stock ratio of external liabilities to assets, and economic performance, as measured by GDP and stock market indices, determine the likelihood of the regime shift. Specifically, an increase in reserve currency debt raises potential capital losses from devaluation and reduces the probability of switching to a low intervention regime. We use a panel of quarterly data starting 1985 through 2004 for a sample of 15 countries, mostly from East Asia and Latin America. We adopt a novel two-step empirical strategy in this paper. First, we measure the policy response of the central bank in two ways, both derived from the monetarist model: a standard exchange market pressure index and a model-based volatility ratio that is endogenized relative to Japan, our "benchmark" floater. We apply regime-switching methods to these "policy response indices." This generates a time-series of unconditional probabilities of switching between high and low intervention. In the second step, we establish a set of variables that explains changes in these probabilities.
\end{abstract}

Key words: Markov regime switching, balance sheet effects, exchange market intervention, panel estimation, emerging markets

JEL Code: F310, F340

World Bank Policy Research Working Paper 3653, July 2005

The Policy Research Working Paper Series disseminates the findings of work in progress to encourage the exchange of ideas about development issues. An objective of the series is to get the findings out quickly, even if the presentations are less than fully polished. The papers carry the names of the authors and should be cited accordingly. The findings, interpretations, and conclusions expressed in this paper are entirely those of the authors. They do not necessarily represent the view of the World Bank, its Executive Directors, or the countries they represent. Policy Research Working Papers are available online at http://econ.worldbank.org.

\footnotetext{
"Shankar (Corresponding author): Department of Economics and International Business School, Brandeis University MS 021, 415 South Street, Waltham, MA 02454; Telephone: 781-736-2265; Fax: 781-7362269; Email: rashmi@brandeis.edu; ; Fiess: Office of the Chief Economist, Latin America and the Caribbean, the World Bank, 1818 H Street NW, Washington DC 20433; telephone: 202-473-5768; Email: nfiess@worldbank.org.
} 


\section{Introduction}

Policy makers' in emerging markets have the usual objectives: high growth, low inflation, and a stable economic environment. Exchange rates have been used to anchor inflation in many of these countries. Equally commonly, these exchange rate based stabilizations tend to end in crises. The literature on exchange rate policy in small, open economies has in fact developed largely in the context of the currency and financial crises experienced by, among others, Mexico (1994-95), several East Asian economies (1997-98), Brazil (1999), and Argentina (2001). Several of these countries moved from crawling pegs to fixed regimes. In other cases, currency boards were followed by large devaluations, which in turn gave way to managed floats or "hard pegs."

In each of the above cases, the crisis occurred because continued compliance to the peg was too costly to be sustained given available policy instruments and resources. Various explanations have been brought forward for why commitment costs might be high: dwindling assets relative to liabilities in the central bank's balance sheet (Dooley, 2000, Chang and Velasco, 1998 and 1999; Cespedes et al., 2004), agent incentives when borrowing is cheap (Chinn and Kletzer, 1999; Hausmann and Velasco, 2004, among others), the interaction between agents' portfolio choices and anticipated exchange rate policy (Chang and Velasco, 2005), or all of the above.

In addition, recent papers emphasize that reversals in the availability of external financing often precede crises. The crisis literature has of course long identified a fall in foreign lenders' demand for domestic financial assets as the key characteristic of a crisis. The key role of private agents' asset choices in influencing monetary and exchange rate policy is highlighted by the "sudden stops" phenomenon (Calvo, 1998). This term is used to capture the idea that when a fixed exchange rate regime is abandoned under crisis conditions, the decision to float is accompanied by a reversal of capital inflows, possibly even capital outflows. This leads to a fall in the current account deficit, which must be shrink as the external credit constraint tightens. In effect, the currency crisis coincides with a financial crisis. A disturbing implication is that sudden stops cause sharper recessions in afflicted countries relative to currency crisis episodes that are not accompanied by the withdrawal of external financing (Calvo and Reinhart, 1999).

It is also widely acknowledged that exchange rate policy in emerging markets has been characterized by shifts between a stronger and weaker commitment to peg, even though volatile policies may introduce costly uncertainty into the economic environment: welfare gains from eliminating policy uncertainty could be as high as 9 percent of trend consumption according to 
Mendoza (1999). The model presented in Chang and Velasco (2005) provides a clue as to why there is policy variability in economies even when there are large potential gains from stabilization. In their model, domestic agents decide the currency composition of their borrowings given which the central bank determines exchange rate policy. The two decisions are made simultaneously: agents' portfolio choices affect the exchange rate and the central bank takes as given the currency denomination of debt when setting policy. "Equilibrium" exchange rate policy thus depends on, and should vary with, the currency composition of the liabilities of the financial system and the private sector.

The different strands of thought on failed exchange rate stabilizations may be brought together as follows. Policy makers in credit-constrained developing countries fix exchange rates in the hope that this will stabilize the economy and thereby stimulate capital flows and investment. The success or failure of this high intervention regime in achieving its objectives will rest on how credible the stabilization is to foreign investors, how well the growth rate picks up in response to capital inflows and to stabilization, how effectively debt is managed, and for how long improved economic performance is maintained. If the economy is unable to absorb capital inflows effectively the result is a wave of over-borrowing during the "boom," which is self-destructive in nature since it creates the necessary and sufficient conditions for the "bust." Intervention policy thus becomes endogenous to performance, which would help explain why, in many emerging markets, destabilizing policy switches have become a regular and debilitating occurrence.

For this reason, our focus will be on the central bank's policy response to over-borrowing (among other fundamentals). At this point we should clarify why the central bank need respond to foreign currency debt accumulation in the first place. The accumulation of reserve currency debt by the private sector and/or the poorly regulated financial sector becomes the central bank's problem largely because the latter is the lender of last resort ${ }^{1}$. "Insurance" might be an additional mechanism through which the central bank becomes vulnerable to the economy-wide balance sheet. The central bank may provide explicit or implicit guarantees to foreign lenders (Dooley, 2000) thereby forging a direct relationship between the overall increase in privately owed foreign debt and an increase in the central bank's contingent liabilities.

\footnotetext{
${ }^{1}$ The literature clearly recognizes this vulnerability of the central bank. The argument has even been made that a benefit of dollarization in such economies is that it eliminates the domestic central bank's function of lender of last resort (Calvo, 2001).
} 
How then would the central bank respond to growing dollarized liabilities? Reserve currency debt can affect the central bank's exchange rate policy in offsetting ways. One would be by increasing the risk of debt default, causing capital inflows to slow or reverse. This puts pressure on central bank reserves and reduces resources available for intervention. A real shock that reduces growth rates could have the same effect: it is well documented that capital inflows are procyclical in developing countries (Kaminsky, 2004). Conversely, if the financial system has dollarized liabilities, there is an incentive for the central bank to avoid capital losses that would result if the home currency were to depreciate. This raises the benefits from continuing to intervene and engenders fear of floating (Calvo and Reinhart, 2002, Chang and Velasco, 2005). Once the costs of intervention outweigh the benefits, the central bank has no choice but to switch from high intervention to low intervention. In many of the countries in our sample, the shift to a floating regime occurs under crisis conditions or when capital flows are dwindling.

To summarize, the growing consensus in the literature is that exchange rate policy emerges from the interaction between agents' portfolio choices, the central bank's role as lender of last resort, and flawed financial institutions. This raises the issue of how central banks' exchange rate policies respond to changing financial and economic circumstances, which we explore by addressing the following questions:

- Does intervention policy exhibit clearly defined cycles?

- What drives these policy cycles?

Our empirical strategy is as follows. We first obtain an explicit policy reaction function for the central bank based on the monetarist model (Girton and Roper 1977; Weymark 1995; Kaminsky and Reinhart 1999). In the monetarist model, exchange market pressure is caused by money market disequilibrium and can therefore be relieved through direct intervention in currency markets. We measure intervention in two different ways, both of which we examine for regime switching behavior. This provides a robustness check.

Policy choice, as reflected by the two measures of intervention, is modeled as an independent two-state Markov process: stabilization or high exchange market intervention and letting it slide or low exchange market intervention. The policy response of the central bank for a given increase in exchange market pressure is larger in the "high" intervention state than in the "low" intervention state. This generates a time series of the probabilities of switching from a high 
intervention regime to a low intervention regime. Next, we identify a set of variables that explains regime switch.

The explanatory variables capture potential "balance sheet effects" and include indicators of economic performance. The balance sheet indicators are the ratio of the stock of external liabilities to assets and the ratio of M0 to reserves. The size of reserve currency debt relative to assets can be thought of as capturing the extent to which the financial system is "leveraged" and is therefore a proxy both for risk of default and for the financial system's exchange risk exposure. The ratio of $\mathrm{MO}$ to foreign reserves, in the absence of capital controls, indicates the size of the central bank's contingent liquid liabilities relative to assets. This is because all money in circulation is a liability of the central bank and, under a high intervention regime, the central bank must stand ready to swap domestic currency for reserve currency at the supported exchange rate. Economic performance is measured by GDP growth, stock market returns, and inflation differentials. We find that balance sheet effects are highly significant in explaining the switch from high to low exchange market intervention, even though the central bank faces offsetting incentives in this context. The results indicate that fear of floating does prevail, and high external liabilities relative to assets significantly increase the likelihood of remaining in the high intervention state, irrespective of which measure of intervention we use. Our sample covers 15 countries, primarily from Latin America and East Asia $^{2}$, over the period encompassing the first quarter of 1985 through the third quarter of 2004.

In the next section we motivate two measures of intervention and sketch the Markov switching model that we fit on these two measures. In Section 2 we discuss the results of the model outlined in Section 1 and present the probabilities that the central bank will switch away from a high intervention policy. In Section 3 we provide the underlying theoretical motivation for our empirical strategy, an overview of the data, the results of the regression analysis, and the estimates of the thresholds over which the regressors signal a policy switch. We conclude in Section 4 that financial and economic performance constrains the central bank's decision to intervene.

${ }^{2}$ The countries in our sample are: Argentina, Australia, Brazil, Chile, Colombia, India, Indonesia, Japan, Germany, Korea, Malaysia, Mexico, New Zealand, Thailand, and Venezuela. 


\section{Section 1: Intervention Indices and Switching}

Here we present a sketch of the monetarist policy reaction function, which is the basis for the two intervention measures used in this paper. These intervention measures are meant to capture the central bank's ex poste reaction to exchange market pressure. The indices are then modeled as following independent, two-state Markov switching process.

\subsection{The Intervention Indices}

The basic assumptions underlying our specification of the intervention indices follow the standard for small, open economy models (Girton and Roper, 1977; Weymark, 1995; Kaminsky and Reinhart, 1999).

The model assumes that the level of foreign prices and the exchange rate both influence domestic prices, even if purchasing power parity does not hold. Foreign prices and foreign interest rates are exogenous, and foreign and domestic interest rates are linked through uncovered parity. Demand for domestic money is increasing in domestic output and decreasing in domestic interest rates. The exchange rate is in equilibrium when domestic asset markets are in equilibrium. $\mathrm{A}$ decrease in the demand for domestic money relative to supply causes the domestic currency to depreciate to its new equilibrium value such that the demand for domestic currency is equal to the supply.

The central bank is responsible for exchange rate policy and may intervene in currency markets to support the value of domestic money at the desired level. This may involve changing domestic money supply unless intervention is sterilized, drawing down, or accumulating foreign reserves. Alternatively, given covered parity, the central bank may adjust interest rates to support the domestic currency. The central bank's intervention policy can be thought of in the following terms. If there is a change in the demand for domestic assets, the exchange rate is under "pressure" to adjust. If the exchange rate is not allowed to adjust to its new shadow value, the central bank must intervene or adjust interest rates to restore equilibrium (Frenkel and Aizenman (1982). The imbalance between domestic currency demand and supply is the wedge between actual and equilibrium exchange rates. This "exchange market pressure" or EMP can be relieved in 
three ways: by allowing the exchange rate to adjust; by altering the interest rate; and/ or through direct intervention, i.e. the sale or purchase of reserve currency assets.

If central banks use both changes in reserves and in interest rates as policy instruments, we can define EMP as in (1), which expresses EMP as a weighted average of changes in the exchange rate, interest rate, and reserves. In other words, if there is exchange market pressure, either the exchange rate or the policy instruments will have to adjust (Girton and Roper, 1977). Since exchange rates are more volatile than reserves (or interest rates), the elasticity $\eta=-\Delta e /(\Delta r+\Delta \mathrm{int})$ is used to convert changes in the policy instrument into equivalent units of changes in the exchange rate (Weymark, 1995; Kaminsky and Reinhart, 1999). The variables are as follows: $e=$ exchange rate; $r=$ foreign reserves; $i=$ interest rate.

$$
E M P_{t}=\Delta e_{t}+\eta\left(\Delta i_{t}-\Delta r_{t}\right)
$$

As intervention implies that reserve changes occur in the opposite direction to changes in interest rates and exchange rates, $\Delta r_{t}$ enters the policy reaction function with a negative sign.

Under conditions of disequilibrium in asset markets therefore, changes in the policy instruments can be used to help bring the supported exchange rate in line with the equilibrium or shadow exchange rate. Since the policy instruments change in response to EMP under a policy of intervention, we can write equation (2):

$$
\Delta r_{t}-\Delta i_{t}=-\bar{\rho} \Delta E M P
$$

$\bar{\rho}$ is the policy response parameter and indicates the extent to which disequilibrium is eliminated through changes in the instruments. When $\bar{\rho}$ is zero, for example, the exchange rate is being allowed to float. In order to determine the extent to which the central bank is intervening, we consider the share of exchange market pressure that is being relieved through changes in the policy instruments or $\omega_{t}$. 


$$
\omega_{t}=\frac{\left(\Delta r_{i t}+\Delta i_{i t}\right)}{\left(\Delta r_{i t}+\Delta i_{i t}\right)+\Delta e / \eta}=\frac{\left(\Delta r_{i t}+\Delta i_{i t}\right)}{E M P_{t}}
$$

We use the monetarist intuition to measure intervention in two ways. The first measure is simply the Weymark formulation contained in equation (3). In equation (4a), we rewrite this as a computable policy response index $\left(P R{ }^{1}{ }^{1} i\right)$ by setting the weight $\eta$ as equal to $\left(\sigma_{\Delta e} / \sigma_{\Delta r}\right)$ (Kaminsky and Reinhart, 1998).

$$
P R I_{i t}^{1}=\frac{\left(\sigma_{\Delta e} / \sigma_{\Delta r}\right)\left(\Delta r_{i t}+\Delta i_{i t}\right)}{\left(\sigma_{\Delta e} / \sigma_{\Delta r}\right)\left(\Delta r_{i t}+\Delta i_{i t}\right)+\Delta e_{i t}}
$$

Since we are only interested in intervention, not in crisis dating, we do not have to impose any arbitrary thresholds on $P R I^{1}$.

The second measure follows from the relationship between policy instrument variability and exchange rate variability inferred by equations (2) and (3). If the exchange rate is pegged, or $\bar{\rho}$ is equal to 1 , the volatility of the exchange rate is zero. Reserves and interest rates will then adjust (in opposite directions) in response to exchange market pressure such that $\omega_{t}$ equals 1 also. If $\bar{\rho}=0$ and the exchange rate is allowed to float, the volatility of the policy instrument relative to the volatility of the exchange rate should be less than one or at the very least should be lower than it would be if the exchange rate was fixed. In equation (4b), this behavior is captured by PRI2, which is the ratio of the volatility of the policy instrument relative to exchange rates in country "i" divided by the same ratio for Japan, our benchmark floater. Both exchange rates are expressed in terms of the US dollar ${ }^{3}$. Again, we do not impose any thresholds on PRI ${ }^{2}$. Both measures therefore can be used to generate unconditional probabilities of switching from one exchange rate regime to the other.

\footnotetext{
${ }^{3}$ We do not use the US dollar as our benchmark since the countries in our sample largely held the US dollar as reserve currency during the period of this paper's analysis.
} 


$$
P R I_{i t}^{2}=\frac{\left[\left(\sigma_{\Delta r}^{2}+\sigma_{\Delta \text { int }}^{2}\right) / \sigma_{\Delta e}^{2}\right]_{i t}}{\left[\left(\sigma_{\Delta r}^{2}+\sigma_{\Delta \text { int }}^{2}\right) / \sigma_{\Delta e}^{2}\right]_{j t}}
$$

Each measure is modeled as following an independent two state Markov switching process, i.e.

$$
P R I_{i t}^{m}-\mu_{i t}\left(S_{t}\right)=\phi\left(P R I_{i t-1}^{m}-\mu_{i t-1}\left(S_{t-1}\right)\right)+\sigma_{i t}\left(S_{t}\right) \varepsilon_{i t} \mid m=1,2
$$

"S", which indicates the intervention state, takes the values $H$ (high) and $L$ (low), such that the response in country "i" relative to country "j" is bigger in state " $\mathrm{H}$ " than in state " $\mathrm{L}$ " for a given level of EMP.

\subsection{Probability of Switching and Balance Sheet Indicators}

For each of the two measures, we specify that the probability of a switch in policy is conditional on the underlying financial and economic performance indicators. The state of policy response, high or low, is assumed to follow an ergodic first-order Markov process characterized by the matrix $\Pi$ consisting of the transition probabilities " $p_{h l}$ " from state $\mathrm{H}$ (high PRI) to L (low PRI) as in Hamilton (1989).

$$
\Pi=\left[\begin{array}{l}
p_{11} p_{21} \\
p_{12} p_{22}
\end{array}\right], p_{h l}=\operatorname{Pr}\left(S_{t}=L \mid S_{t-1}=H\right)
$$

Following Kim and Nelson (1999), the unconditional probability of being in state $L$, based on the knowledge of the complete PRI series, can be calculated at each date, T.

$$
\pi_{h l T}=\operatorname{Pr}\left(S_{t}=L \mid P R I_{1}^{m}, \ldots, P R I_{T}^{m}\right)
$$


These smoothed probabilities are reported in the next section, along with the filtered probabilities (over the complete time series).

$$
\pi_{h l t}=\operatorname{Pr}\left(S_{t}=L \mid P R I_{1}^{m}, \ldots, P R I_{t}^{m}\right)
$$

Equation 9 estimates the impact of a change in our economic and financial performance indicators on the likelihood of a policy response switch at each date:

$$
\pi_{h l T}=a_{1}+a_{2} Z_{T-n}
$$

Here $Z$ is the set of explanatory variables, and $\mathrm{n}$ refers to the number of lags considered. We will estimate equation 8 in Section 2 with the objective of identifying policy switching between periods of high and low exchange rate intervention over the time period 1985 through 2004. This generates a time series of unconditional probabilities of switching to a low intervention regime. In Section 3 , we estimate equation 9 , and thus condition the regime shift probabilities on the set of country specific fundamentals in $Z$.

\section{Section 2: Identifying the Policy Cycles - Country Specific Markov Switching Models}

Regime-switching methods have been widely applied in both economics and finance ever since Hamilton's (1989) study of business cycle dynamics. In particular, these techniques have been used to explain the forward bias in exchange rate forecasts and to improve out-of-sample forecasts of exchange rates (Engel and Hamilton, 1990; Kaminsky, 1993; Engel, 1994), to analyze the volatility of particular exchange rates (Bazdresch and Werner, 2005), to identify cycles in monetary policy preferences (Owyang and Ramey, 2004), and in tests of the switching properties of fundamentals in a monetarist exchange rate model (Frommel et al., 2005). The popularity of this approach relates to its greater power to distinguish across fluctuations between persistent regimes, whereas vector autoregression methods are, for example, appropriate only if shocks are transitory.

We estimate country-specific Markov Switching autoregressive processes (Krolzig, 1997) with regime shifts in the mean of $P R I^{1}$ and $P R I^{2}$. As a robustness check, we opt to fit the regimeswitching model over quarterly data for $\mathrm{PRI}^{1}$ and over monthly data for $\mathrm{PRI}{ }^{2}$. As the variables in 
the econometric analysis of section 3 are at quarterly frequency, $\mathrm{PR} \mathrm{I}^{2}$ is transformed to quarterly frequency by taking period averages. All data are from the IMF (source and line numbers listed in the appendix), including debt and asset flows from which the stocks of external liabilities and assets have been cumulated (with the appropriate valuation adjustment ${ }^{4}$ ).

We allow for regime-specific heteroskedastic errors and base model selection on the Schwarz statistics. Our results appear generally robust to lag length. We find regime switching in the mean for all 15 countries. ${ }^{5}$ The regime dates associated with both policy intervention indices are reported in Appendix 1. For most countries, $P R I^{1}$ and $P R I^{2}$ identify similar regime switching points. Compared to $\mathrm{PRI}^{1}$, regimes based on $\mathrm{PRI}^{2}$ appear more persistent. In particular for the high-income countries in our sample (Australia, Germany, Japan and New Zealand), PRI ${ }^{1}$ generates policy cycles of shorter duration and more frequent regime changes. The higher volatility of $P R I^{1}$ is explained by the fact that the difference in the mean of high and low intervention states is much less pronounced and in the case of Japan only borderline significant. Based on PRI ${ }^{1}$, regime classification is far more clear-cut if countries go through periods of high versus low intervention (developing countries) as compared to low versus some intervention (non-developing countries). It is therefore not surprising that PRI2, scaled by Japan's policy response index, is much less volatile for both developing and non-developing countries, as small fluctuations in the degree of intervention are filtered out.

${ }^{4}$ See Kraay et al., 2000.

${ }^{5}$ Model specifications for country-specific MS-AR models are available from the authors upon request. 
Figure 1: Brazil (PRI')

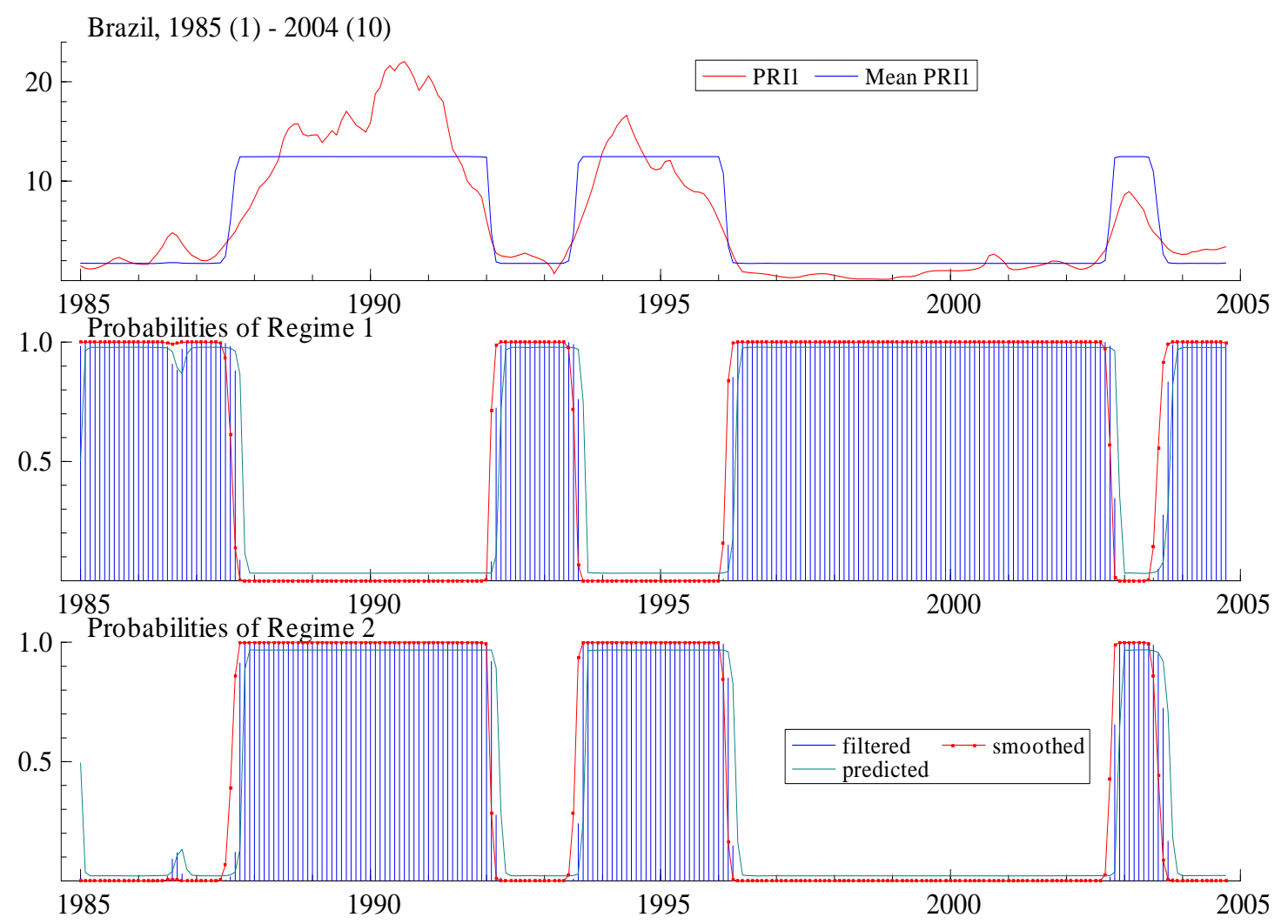

Figure 1 depicts the regime probabilities based on $\mathrm{PRI}^{2}$ for Brazil over high (regime 1) and low (regime 2) exchange rate intervention periods. The identified regimes correspond closely to Brazil's macro economic performance since the mid-1980s and suggest three episodes of floating (regime 2) for Brazil: the hyperinflation period following the failed 1986 Crucado Plan, the hyperinflationary period preceding the 1995 Real plan and a brief period following the 2002 presidential election, when speculation about Brazil's presidential succession generated a high degree of uncertainty about macroeconomic stability and pressure on Brazil's currency.

The Real plan successfully used the exchange rate as an anchor for price stabilization and the peg to the US dollar was abandoned in 1999. While we do not identify a regime switch to floating at the end of this fixed regime, we register a moderate increase in PRI 2 relative to 1999.

Indonesia (Figure 2) shows a clear regime switch to floating following the 1997 Asia crisis and Chile (Figure 3) exhibits a preference for floating since 2000. Appendix 2 contains the graphs for the full sample, along with the dates for the regime changes. The large swings in the German cycle towards the end of the sample are largely due to transfer of reserves to the European central bank. 
Figure 2: Indonesia
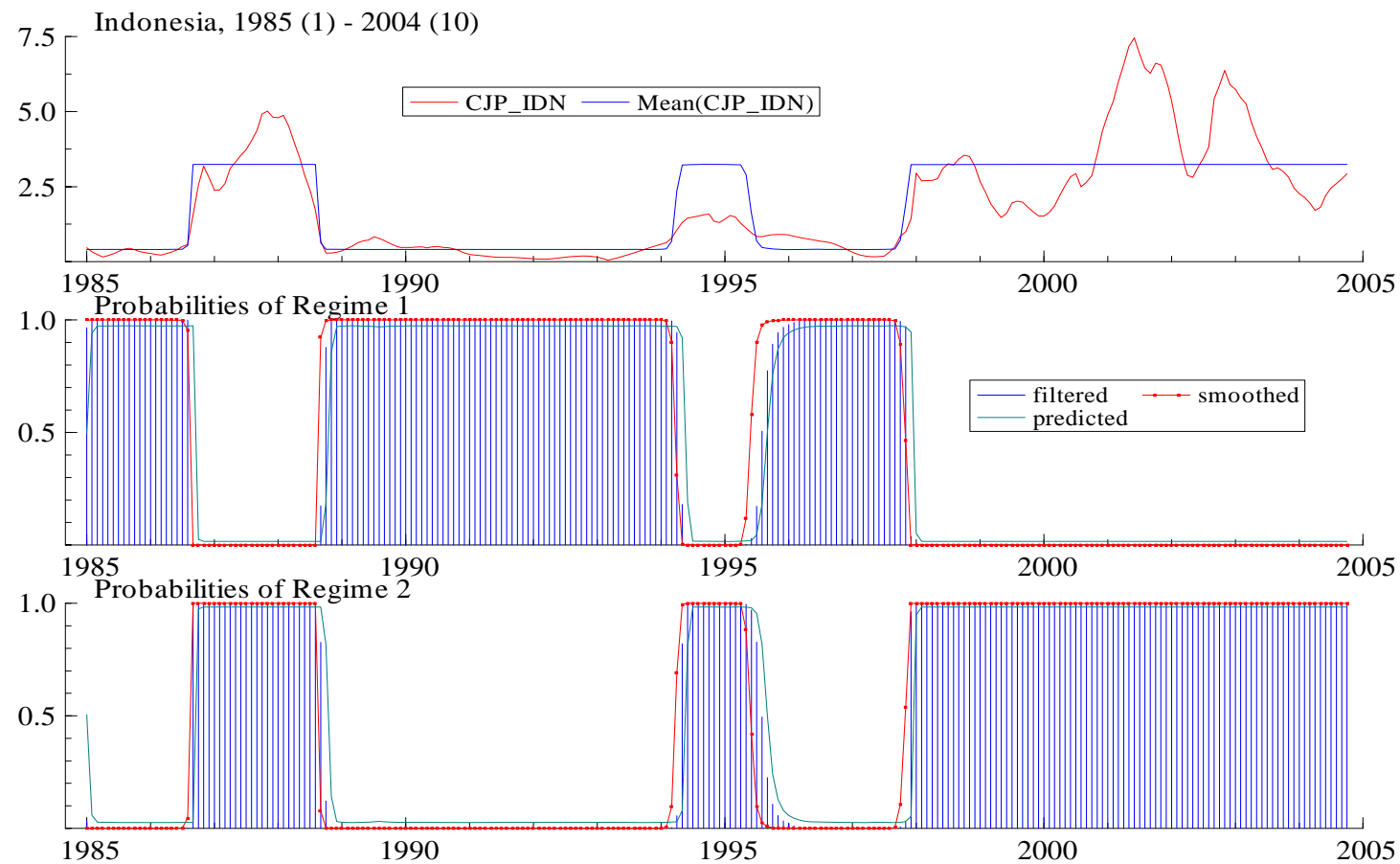

Figure 3: Chile
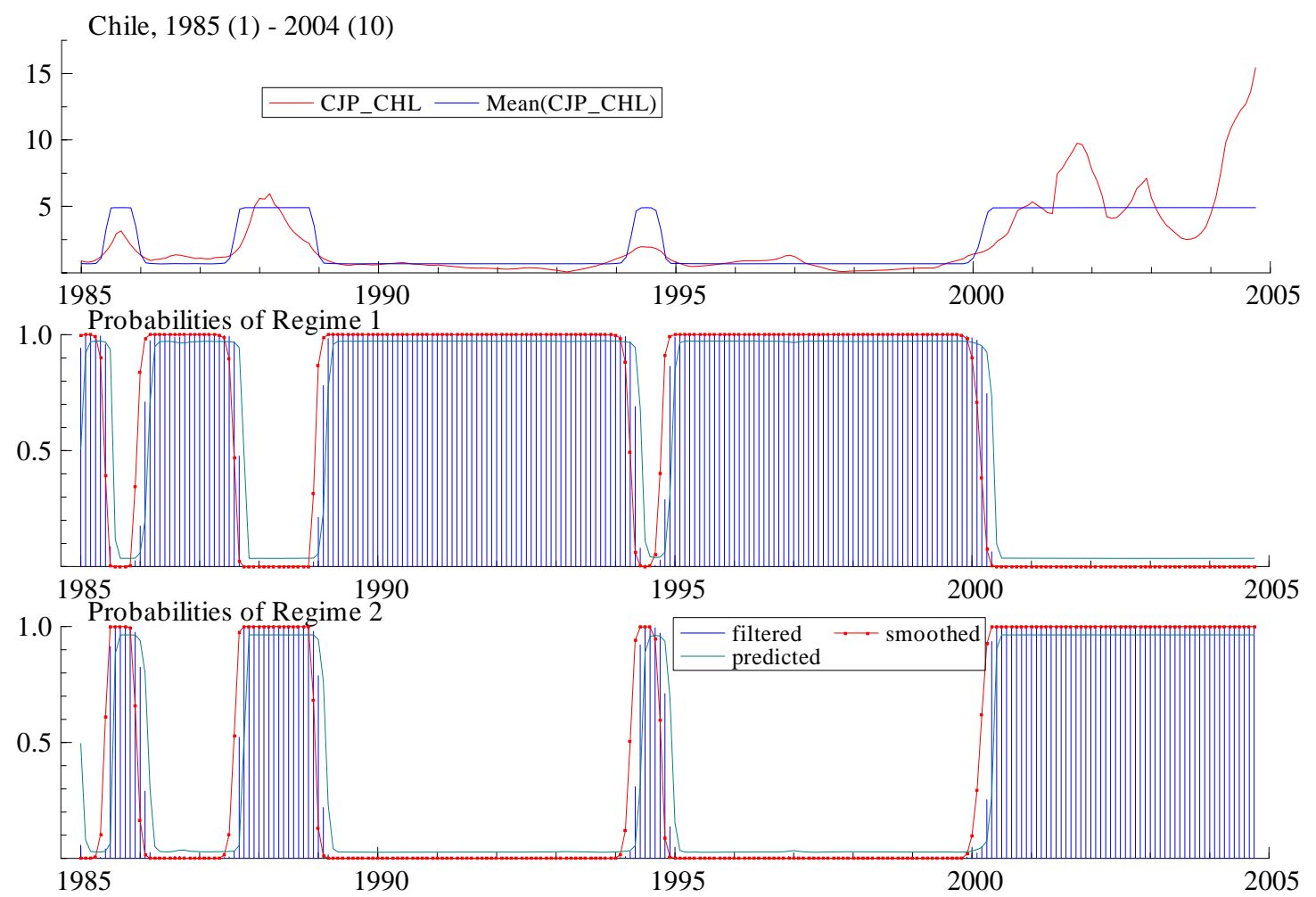


\section{Section 3: Panel Regressions: Rationale and Results}

Theoretical Motivation

Our econometric specification for the explanation of exchange rate policy cycles is motivated by the ideas formalized by the newer breed of financial and currency crisis models. These models form a growing and influential literature built around the idea that the sustainability of the exchange rate regime is largely determined by agents' portfolio choices (Calvo and Reinhart 1999, Chinn and Kletzer 1999, Dooley 2000, Calvo 2001, Manasse et al 2003, Cespedes et al 2004, Hausman and Velasco 2004, Chang and Velasco 2005), the vulnerability of the central bank given its role as lender of last resort, and the moral failure generated by the monetary authorities' support and imperfect financial sector, which further fuels the credit boom. The rationale underpinning these models is that an exchange rate policy can only be sustained as long as the costs of intervention do not exceed the benefits. This, as we have emphasized elsewhere in this paper, motivates us to model directly the central bank's decision to intervene.

The theoretical basis of our econometric specification can be sketched as follows. Consider a small, credit constrained, and open economy. Purchasing power parity may or may not hold. Domestic and foreign interest rates are linked through the risk premium, which therefore determines the relative demand for domestic assets in a manner consistent with interest parity. There are four agents in this model. Foreign creditors lend, through domestic financial intermediaries, to domestic producers. Returns on domestic assets held by creditors, domestic and foreign, must be higher than that on foreign assets if capital inflows are to manifest. The central bank can help here by insuring foreign lenders and reducing exchange risk by committing to intervene if necessary. The peg is to the dollar, and the central bank will use its reserves to preserve equilibrium in the market for domestic currency assets. The cost of sustaining this policy will depend on availability of reserves, the extent to which capital inflows eliminate the need for intervention, and demand for domestic currency assets.

There is an informational asymmetry between foreign lenders and domestic banks. Foreign lenders cannot observe the cost of financial regulation (or the domestic intermediaries' incentive to screen domestic borrowers). They can however observe the insurance burden on the central bank. 
Capital inflows generate both a monetary expansion and an increase in external debt relative to assets. Asset prices boom - typically those of land and stocks. Domestic consumption is relatively cheap and the real exchange rate becomes overvalued. The informational asymmetry between foreign lenders and domestic banks reduces the latter's incentive to evaluate domestic projects and results in over borrowing. A sufficient quantity of bad loans later, the economy slows down. Estimates of the cost of insurance are revised upwards as creditors' expectations are revised to account for the likelihood that the central bank's contingent liabilities become actual liabilities. Stock market indices start to slide, and stock market returns become more volatile. This leads to a higher risk premium on domestic assets. Since the available supply of external credit has a negative relationship with the risk premium, capital outflows or slowing capital inflows are the result (See appendix 4 for a confirmation that correlations between private capital inflows and other key variables are statistically significant). The appropriate policy response would be to raise domestic interest rates or to allow the domestic currency to depreciate once portfolios are reallocated away from domestic assets and the cost of intervention becomes too high. There is a real incentive to delay the switch to low intervention, however, even as the bubble bursts, the demand for domestic assets starts to fall, and pressure builds in the exchange market. Even though the cost of maintaining high intervention increases as the monetary base expands, capital inflows slow down, and the economy slides into recession, a higher share of external in total contingent liabilities increases the authorities exchange risk exposure. Devaluation would lead to potentially large capital losses therefore on reserve currency debt, which generates a fear of floating effect (Reinhart, 2000). Which effect dominates and how the economy's balance sheet affects the central bank's decision is a key component of our empirical analysis. We can therefore model the regime switch as being driven by the predictors in Table 1 : 
Table 1: Likely predictors

Dependent Variable: Probability of switching to floating

\begin{tabular}{|c|c|}
\hline Control variables $\left(\mathrm{X}_{\mathrm{it}}\right)$ & Relationship with Dependent Variable: $\operatorname{Pr}($ floating) \\
\hline $\begin{array}{l}\text { Stock of external liabilities/stock of } \\
\text { external assets }\end{array}$ & Negative; raises the cost of switching from fixed. \\
\hline $\begin{array}{l}\text { GDP growth; growth in stock } \\
\text { market indices }\end{array}$ & $\begin{array}{l}\text { Negative; negative growth is the result of the financial failure, which raises } \\
\text { the cost of fixing. }\end{array}$ \\
\hline Real exchange rate ${ }^{6}$ & $\begin{array}{l}\text { Negative; cheap consumption fueled by the lending boom leads to an } \\
\text { overvaluation of the real exchange rate. }\end{array}$ \\
\hline Mo/reserves & Positive; easy money raises the cost of intervention. \\
\hline Volatility in stock market indices & $\begin{array}{l}\text { Positive; uncertain returns further discourages capital inflows; the cost of } \\
\text { intervention increases as external credit becomes less available. }\end{array}$ \\
\hline
\end{tabular}

\section{Descriptive Statistics, Econometric Model Specification and Results}

\section{Descriptive statistics}

Before reporting the regression results, we present descriptive statistics for the control variables listed in Table 1 across different phases of the two regimes. Since exchange rate regime changes have often occurred in response to crises in emerging markets, we window out the four quarters leading to (pre-float) and following (post-float) the switch from fixed to floating. Table 2 summarizes these descriptive statistics for the entire panel over the four sub-periods: fixed, prefloat, post-float and float. Country-wise descriptive statistics are reported in the appendix.

During the pre-float regime, debt to asset ratios, GDP, and ratio of M0 to total reserves all grow at a significantly higher rate than during the fixed regime. The real effective exchange rate index, stock market, and inflation variables do not appear to behave significantly different between fixed and pre-float periods. When comparing floating to fixed exchange rate regimes, we do not find any significant differences in GDP growth, debt to asset ratios, and real exchange rate dynamics. Inflation, growth in MO relative to reserves, and stock market volatility are significantly higher in the floating regime than in the fixed exchange rate regime, as expected.

\footnotetext{
${ }^{6}$ Results of stationarity tests performed on the transformed variables indicate that only the natural log of the real effective exchange rate index is marginally non-stationary (I(1)).
} 
The differences that signal a change in intervention policy are not large, at least for the balance sheet indicator: if these numbers are interpreted as estimates of thresholds, there is only a 122 per cent increase in liabilities relative to assets between pre and post floating on the one hand, and sustained fixed and floating on the other. Since external asset stock measures are cumulated from asset flows reported in the balance of payments, which are underestimates at best, the assets are largely central bank reserves. As these reserves fall, even a small increase in external debt can render intervention unsustainable. The output growth slow down is large however, across the same comparison points: around three per cent. The same is true for the ratio of $\mathrm{MO}$ to reserves, which is a measure of the central bank's contingent liabilities. The ability to sustain high intervention is associated with a fall in the growth of reserve money: the number jumps to twenty percent in the pre-floating phase.

Table 2: Descriptive Statistics

\begin{tabular}{|c|c|c|c|c|c|c|c|c|}
\hline & Sample & $\begin{array}{l}\text { Debt/asset } \\
\text { ratio } \\
\text { (natural logs) }\end{array}$ & $\begin{array}{l}\text { GDP } \\
\text { growth }\end{array}$ & $\begin{array}{l}\text { Stock } \\
\text { market } \\
\text { volatility }\end{array}$ & $\begin{array}{l}\text { REER } \\
\text { change }\end{array}$ & $\begin{array}{l}\text { Change in } \\
\text { MO/reserves }\end{array}$ & $\begin{array}{l}\text { Change in } \\
\text { inflation } \\
\text { differential }\end{array}$ & $\begin{array}{l}\text { Inflation } \\
\text { "acceleration" } \\
\text { relative to US } \\
\text { inflation }\end{array}$ \\
\hline (1) & Fixed & 0.48 & 0.04 & 0.53 & 0.00 & -0.01 & -0.03 & -0.04 \\
\hline (2) & Pre-float & 0.68 & 0.01 & 0.49 & -0.01 & 0.20 & -0.02 & -0.01 \\
\hline (3) & Post-float & 0.60 & -0.07 & 0.59 & 0.02 & 0.22 & 0.02 & 0.00 \\
\hline (4) & Float & 0.40 & 0.05 & 0.67 & 0.00 & 0.26 & 0.02 & 0.05 \\
\hline \multicolumn{9}{|c|}{ t-tests } \\
\hline$(1) \neq(2)$ & $\begin{array}{l}p \text {-value } \\
P>|t|\end{array}$ & 0.0321 & 0.014 & 0.354 & 0.877 & 0.000 & 0.596 & 0.591 \\
\hline$(1) \neq(4)$ & $\begin{array}{l}p \text {-value } \\
P>|t|\end{array}$ & 0.3157 & 0.805 & 0.001 & 0.744 & 0.000 & 0.0061 & 0.007 \\
\hline
\end{tabular}

Panel Specification and Analysis:

For the entire panel, we model the probability of floating as being dependent on the control variables contained in $X_{i t}$ (listed in Table 1). Equation 10 specifies that there are country fixed effects (captured by $\alpha_{i}$ for the ith country).

$\operatorname{Pr}(\text { floating })_{i t}=\alpha_{i}+\beta^{\prime}(X)_{i t}+\varepsilon_{i t}$ 
The results of the panel fixed effects regressions presented in Tables 5 and 6 are very similar even though the dependent variables are defined differently. Table 3 presents the results for the benchmarked volatility measure of intervention (PRI2), while Table 4 presents the results for $P R{ }^{1}$. The latter measure is far more volatile, especially around crises points, but the econometric results do not show significant differences, even when the marginal effects are dissimilar.

The ratio of external liabilities to assets is robust to changes in specification and across measures of intervention $\left(\mathrm{PRI}^{1}\right.$ and $\left.\mathrm{PRI}^{2}\right)$ and always has a negative impact on the probability of floating. Balance sheet effects therefore clearly do matter, which is in line with our central idea that large potential capital losses on debt denominated in the reserve currency will push the central bank to intervene in order to avoid devaluation. The squared liabilities to assets ratio captures whether there is a change at a higher level of this ratio. While it is always negative, the squared ratio is significant only in specification (4), which also has the highest overall significance, and the highest adjusted R-square. The threshold analysis reported in Table 2 suggests that while the "fear of floating" effect does delay the switch to low intervention, there is a significant increase in the debt to asset ratio during the sub-period classified as pre-floating. This could be because intervention is not sustainable at high levels of debt. The economic performance indicators also have the expected signs. Falling growth rates and stock market returns do appear to increase the cost of intervention. Higher stock market volatility has the same effect as slowing economic performance: it increases the probability of abandoning intervention and switching out of the fixed regime. This is most likely explained by the fact that stock market volatility captures returns uncertainty and an increasingly lower likelihood that capital inflows will be available to help support the fixed regime (correlations are reported in Appendix 4).

Measures of volatility in the ratio of external liabilities to assets do not show up as significant. However the change in the ratio of $\mathrm{MO}$ to total reserves captures growth in uncovered total contingent liabilities and is a positive predictor of the probability of floating. It reflects the growing insurance burden of the central bank and therefore is directly related to the rising cost of intervention needed to avoid a regime change. 
Table 3: Dependent Variable is Intervention Index or PRI' (Equation 4b):

\begin{tabular}{|c|c|c|c|c|c|c|}
\hline $\begin{array}{l}\text { All variables in natural logs or } \\
\text { log first differences }\end{array}$ & (1) & (2) & (3) & (4) & (5) & (6) \\
\hline \multirow{2}{*}{$\begin{array}{l}\text { External liabilities to } \\
\text { Assets (1 quarter lag) }\end{array}$} & -0.162 & -0.092 & -0.267 & -0.150 & -0.062 & -0.177 \\
\hline & $(5.21)^{\star \star}$ & $(3.16)^{\star *}$ & $(5.64)^{\star \star}$ & $(5.10)^{\star \star}$ & $(2.35)^{\star}$ & $(4.08)^{\star \star}$ \\
\hline \multirow{2}{*}{$\begin{array}{l}\text { External liabilities to } \\
\text { Assets (1 quarter lag) squared }\end{array}$} & -0.018 & 0.001 & & -0.031 & -0.000 & \\
\hline & (1.47) & $(0.10)$ & & $(2.64)^{\star \star}$ & $(0.01)$ & \\
\hline \multirow{2}{*}{$\begin{array}{l}\text { Volatility in stock market index } \\
\text { (over previous four quarters) }\end{array}$} & 0.152 & 0.141 & 0.295 & & & \\
\hline & $(2.66)^{\star \star}$ & $(2.81)^{\star \star}$ & $(3.85)^{\star \star}$ & & & \\
\hline \multirow{2}{*}{$\begin{array}{l}\text { Change in GDP (over previous } \\
\text { four quarters) }\end{array}$} & -0.352 & & -0.535 & -0.339 & & -0.545 \\
\hline & $(3.28)^{\star \star}$ & & $(3.88)^{\star \star}$ & $(3.22)^{\star \star}$ & & $(3.84)^{\star \star}$ \\
\hline \multirow{2}{*}{$\begin{array}{l}\text { Real Effective Exchange Rate } \\
\text { Index }\end{array}$} & -0.224 & -0.117 & -0.253 & -0.310 & -0.214 & -0.354 \\
\hline & $(2.24)^{\star}$ & $(1.20)$ & $(1.81)$ & $(3.17)^{\star \star}$ & $(2.32)^{*}$ & $(2.64)^{\star \star}$ \\
\hline \multirow{2}{*}{$\begin{array}{l}\text { Change in ratio of } \mathrm{M} 0 \text { to total } \\
\text { reserves (over previous four } \\
\text { quarters) }\end{array}$} & 0.168 & 0.182 & 0.133 & 0.197 & 0.232 & 0.123 \\
\hline & $(2.82)^{\star \star}$ & $(3.58)^{\star \star}$ & $(1.62)$ & $(3.44)^{\star \star}$ & $(5.44)^{\star \star}$ & (1.45) \\
\hline \multirow{2}{*}{$\begin{array}{l}\text { Change in stock market index } \\
\text { (over previous two quarters) }\end{array}$} & & -0.028 & & & -0.028 & \\
\hline & & $(3.22)^{\star \star}$ & & & $(3.45)^{\star \star}$ & \\
\hline \multirow{3}{*}{$\begin{array}{l}\text { Coefficient of variation in external } \\
\text { liabilities to asset ratio (over } \\
\text { previous four quarters) }\end{array}$} & & & -0.131 & & & \\
\hline & & & & & & \\
\hline & & & $(0.81)$ & & & \\
\hline \multirow{2}{*}{$\begin{array}{l}\text { Growth in the change in inflation } \\
\text { difference over the US }\end{array}$} & & & 0.050 & & & 0.131 \\
\hline & & & $(0.42)$ & & & (1.08) \\
\hline \multirow{2}{*}{$\begin{array}{l}\text { Volatility in change in external } \\
\text { liabilities to asset ratio (over } \\
\text { previous four quarters) }\end{array}$} & & & & & & -0.091 \\
\hline & & & & & & $(178)$ \\
\hline \multirow[t]{2}{*}{ Constant } & 1.417 & 0.891 & 1.428 & 1.901 & 1.405 & 2.096 \\
\hline & $(3.06)^{\star \star}$ & (1.96) & $(2.19)^{\star}$ & $(4.25)^{\star \star}$ & $(3.30)^{\star \star}$ & $(3.40)^{\star \star}$ \\
\hline Observations & 641 & 690 & 284 & 704 & 715 & 311 \\
\hline \multirow[t]{2}{*}{ F-test for overall significance } & 13 & 14 & 11 & 13 & 14 & 11 \\
\hline & 0.11 & 0.09 & 0.24 & 0.10 & 0.09 & 0.17 \\
\hline
\end{tabular}

Absolute value of t statistics in parentheses; * Significant at 5\%; ** significant at 1\%; Marginal effects reported with zstatistics in parentheses; Results of stationarity tests on transformed variables available from authors upon request. Natural log of Real Effective Exchange Rate Index is marginally I(1). 
Table 4: Dependent Variable is Intervention Index or PRI ${ }^{1}$ (Equation 4a):

\begin{tabular}{|c|c|c|c|c|c|c|}
\hline $\begin{array}{l}\text { All variables in natural logs or } \\
\text { log first differences }\end{array}$ & (1) & (2) & (3) & (4) & (5) & (6) \\
\hline \multirow{2}{*}{$\begin{array}{l}\text { External liabilities to } \\
\text { Assets (1 quarter lag) }\end{array}$} & -0.100 & -0.091 & -0.149 & -0.089 & -0.069 & -0.090 \\
\hline & $(3.60)^{\star \star}$ & $(3.57)^{\star \star}$ & $(3.29)^{\star \star}$ & $(3.38)^{\star \star}$ & $(2.95)^{\star \star}$ & $(2.18)^{\star}$ \\
\hline \multirow{2}{*}{$\begin{array}{l}\text { External liabilities to } \\
\text { Assets (1 quarter lag) squared }\end{array}$} & -0.048 & -0.038 & & -0.059 & -0.035 & \\
\hline & $(4.46)^{\star \star}$ & $(4.26)^{\star \star}$ & & $(5.74)^{\star \star}$ & $(3.96)^{\star \star}$ & \\
\hline \multirow{2}{*}{$\begin{array}{l}\text { Volatility in stock market index } \\
\text { (over previous four quarters) }\end{array}$} & 0.161 & 0.087 & 0.264 & & & \\
\hline & $(3.12)^{\star \star}$ & $(1.92)$ & $(3.46)^{\star \star}$ & & & \\
\hline \multirow{2}{*}{$\begin{array}{l}\text { Change in GDP (over previous } \\
\text { four quarters) }\end{array}$} & -0.455 & & -0.397 & -0.489 & & -0.463 \\
\hline & $(4.70)^{\star \star}$ & & $(2.88)^{\star \star}$ & $(5.15)^{\star \star}$ & & $(3.38)^{\star \star}$ \\
\hline \multirow{2}{*}{$\begin{array}{l}\text { Real Effective Exchange Rate } \\
\text { Index }\end{array}$} & -0.215 & -0.124 & -0.224 & -0.236 & -0.211 & -0.247 \\
\hline & $(2.42)^{\star}$ & $(1.44)$ & (1.67) & $(2.72)^{\star \star}$ & $(2.58)^{\star}$ & $(1.96)$ \\
\hline \multirow{2}{*}{$\begin{array}{l}\text { Change in ratio of } \mathrm{M} 0 \text { to total } \\
\text { reserves (over previous four } \\
\text { quarters) }\end{array}$} & 0.077 & 0.242 & 0.168 & 0.115 & 0.249 & 0.160 \\
\hline & (1.42) & $(5.28)^{\star \star}$ & $(2.05)^{*}$ & $(2.22)^{\star}$ & $(6.47)^{\star \star}$ & $(1.93)$ \\
\hline \multirow{2}{*}{$\begin{array}{l}\text { Change in stock market index } \\
\text { (over previous two quarters) }\end{array}$} & & -0.013 & & & -0.015 & \\
\hline & & $(1.67)$ & & & $(2.07)^{\star}$ & \\
\hline \multirow{2}{*}{$\begin{array}{l}\text { Coefficient of variation in external } \\
\text { liabilities to asset ratio (over } \\
\text { previous four quarters) }\end{array}$} & & & 0.187 & & & \\
\hline & & & $(125)$ & & & \\
\hline \multirow{2}{*}{$\begin{array}{l}\text { Growth in the change in inflation } \\
\text { difference over the US }\end{array}$} & & & 0.153 & & & 0.170 \\
\hline & & & (1.48) & & & (1.63) \\
\hline \multirow{2}{*}{$\begin{array}{l}\text { Volatility in change in external } \\
\text { liabilities to asset ratio (over } \\
\text { previous four quarters) }\end{array}$} & & & & & & -0.056 \\
\hline & & & & & & (1 17) \\
\hline \multirow{2}{*}{ Constant } & 1.479 & 1.092 & 1.393 & 1.662 & 1.530 & 1.717 \\
\hline & $(3.60)^{\star *}$ & $(2.71)^{\star *}$ & $(2.21)^{\star}$ & $(4.16)^{\star \star}$ & $(4.04)^{\star \star}$ & $(2.95)^{\star \star}$ \\
\hline Observations & 696 & 733 & 313 & 759 & 758 & 343 \\
\hline F-test for overall significance & $<1 \%$ & $<1 \%$ & $<1 \%$ & $<1 \%$ & $<1 \%$ & $<1 \%$ \\
\hline
\end{tabular}

Absolute value of $t$ statistics in parentheses; * Significant at 5\%; ** significant at 1\%; Marginal effects reported with zstatistics in parentheses; Results of stationarity tests on transformed variables available from authors upon request. Natural log of Real Effective Exchange Rate Index is marginally I(1). 


\section{Section 4: Conclusion}

There is a growing body of evidence on the interaction between economy's balance sheet and the sustainability of the exchange rate regime. This paper contributes to the literature by modeling the central bank's intervention policy directly as a function of country-specific fundamentals that reflect such balance sheet effects. We adopt a novel empirical strategy in order to shed light on the key constraints on exchange rate policy. First, we measure intervention in two ways and model both measures as following independent Markov processes. This enables us to identify well defined switching behavior between high and low intervention regimes. Next, we condition the likelihood of the regime switch on a wide range of macroeconomic while controlling for country fixed effects.

We find strong support for the thesis that financial responsibility determines the sustainable level of intervention across our sample of 15 Latin American and East Asian countries. This was found to be true not only around points of crisis. Boom-bust cycles less dramatic than those observed during crises are observed on a fairly regular basis for most of the countries in our sample, as evident from the graphs displayed in Section 2 and in Appendix 2.

Our primary focus is to predict the likelihood of a change in the central bank's policy choice conditional on rising external debt and contingent liabilities. We expect higher reserve currency debt constrains the central bank's intervention policy in at least two different ways. These two mechanisms work in opposing directions. For one, the burden of intervention is more difficult to sustain as the central bank's uncovered contingent liabilities rise, given limited reserves and unreliable capital inflows. At the same time, devaluation implies capital losses on external debt and generates "fear of floating" (Reinhart, 2002). Our econometric results indicate that the fear of floating effect dominates: the likelihood of moving from high to low intervention is significant and decreasing in the ratio of external liabilities to assets. However, as the threshold analysis in Section 3 indicates, there is a large increase in the ratio of external liabilities to assets in the pre-floating period. This suggests that high reserve currency debt does reduce the central bank's willingness and ability to intervene in currency markets. This constraint on the policy maker is tighter when capital inflows are dwindling or in a sudden stop situation (Calvo,1998). Interestingly enough, for most variables we found no significant difference in performance across fixed and floating regimes that are sustained (turning points are one year windows at both ends of the regime), though 
expected inflation and stock market volatility are significantly higher under floating relative to fixed. The higher macroeconomic volatility under floating creates the desire to stabilize, which is typically the rationale for adopting the high intervention regime.

These results are robust across alternative measures of intervention and changes in specification and are evidence that there are key constraints that drive the policy regime in a systematic way. High inflation creates the incentive to fix. Worsening debt, increasing contingent liabilities, rising stock market volatility, and declining rates of growth determine the likelihood of switching away from the fixed regime. We have made a contribution to the broader literature that seeks to clarify the constraints on central bankers and decision-makers in emerging markets. 


\section{References:}

Aizenman, J. and Jacob A. Frenkel, 1982. "Aspects of the Optimal Management of Exchange Rates," Journal of International Economics, 13, pp. 231-256.

Bazdresch, Santiago and Alejandro Werner, 2005. "Regime switching models for the Mexican peso," Journal of International Economics, Volume 65, Issue 1, pp. 185-201.

Calvo, Guillermo A., 1998. "Capital flows and Capital-market Crises: The Simple Economics of Sudden Stops," Journal of Applied Economics, Vol. 1, No. 1, pp. 35-54.

Calvo, Guillermo A. and Carmen Reinhart, "Capital Flow Reversals, the Exchange Rate Debate, and Dollarization," Financial Development, Vol. 36, No. 3.

Chang, Roberto and Andres Velasco, 1998. The Asian Liquidity Crisis. NBER Working Paper 6796.

Chang, Roberto and Andres Velasco, 1999. Liquidity Crises in Emerging Markets: Theory and Policy. NBER Working Paper 7272.

Chang, Roberto and Andres Velasco, 2005. "Monetary Policy and the Currency Denomination of Debt: A Tale of Two Equilibria," Kennedy School of Government Working Paper Series, Harvard University, Cambridge, Massachusetts.

Céspedes, Luis Felipe, Roberto Chang, and Andrés Velasco, 2004. "Balance Sheets and Exchange Rate Policy," American Economic Review, Vol. 94, No. 4.

Chinn, Menzie and Kenneth Kletzer, 2001. "Imperfect Information, Domestic Regulation and Financial Crises," in Reuven Glick, Ramon Moreno and Mark Spiegel (editors) Financial Crises in Emerging Markets (Cambridge: Cambridge University Press, 2001): 196-237.

Dooley, Michael P., 2000. A Model of Crises in Emerging Markets. The Economic Journal 110(460), pp. 256-272.

Engel, Charles, 1994. "Can the Markov switching model forecast exchange rates?" Journal of International Economics, Volume 36, Issues 1-2, pp. 151-165.

Engel, Charles and James D. Hamilton, 1990, "Long Swings in the Dollar: Are They in the Data and Do Markets Know It?" The American Economic Review, Vol. 80, No. 4, pp. 689-713.

Frömmel, Michael, Ronald MacDonald and Lukas Menkhoff, 2005. "Markov switching regimes in a monetary exchange rate model," Economic Modeling, Volume 22, Issue 3, pp. 485-502.

Girton, Lance and Don Roper, 1977. "A Monetary Model of Exchange Market Pressure Applied to the Postwar Canadian Experience," The American Economic Review, Vol. 67, No. 4, pp. 537-548

Hausmann, Ricardo and Andres Velasco, 2004. "The Causes of Financial Crises: Moral Failure Versus Market Failure," Kennedy School of Government Working Paper Series, Harvard University, Cambridge, Massachusetts. 
Hamilton, James D., 1989. "A New Approach to the Economic Analysis of Non-stationary Time Series and the Business Cycle," Econometrica, Vol. 57, No. 2, pp. 357-384.

Kaminsky, Graciela, 1993. "Is There a Peso Problem? Evidence from the Dollar/Pound Exchange Rate, 1976-1987," The American Economic Review, Vol. 83, No. 3, pp. 450-472

Kaminsky, Graciela L. and Carmen M. Reinhart, 1999. "The Twin Crises: The Causes of Banking and Balance-Of-Payments Problems," The American Economic Review, Vol. 89, No. 3, pp. 473-500.

Kaminsky, Graciela L., Carmen M. Reinhart, and Carlos A. Vegh, 2004. "When it Rains, it Pours: Procyclical Capital Flows and Macroeconomic Policies," NBER Macroeconomics Annual, National Bureau of Economic Research, Inc.

Keller, Christian, Christoph Rosenberg, Nouriel Roubini and Brad Setser, 2002. "The Balance Sheet Approach to Financial Crises", WP/02/210, International Monetary Fund, Washington DC.

Kim, Chang-Jin and Charles R. Nelson, 1999. "Has the U.S. Economy Become More Stable? A Bayesian Approach Based on a Markov-Switching Model of the Business Cycle," The Review of Economics and Statistics, Vol. 81, No. 4, pp. 608-616.

Kraay, Aart, Norman Loayza, Luis Serven, Jaume Ventura, 2000. Country Portfolios. NBER Working Paper No.7795.

Krolzig, Hans-Martin (1997). Markov-Switching Vector Autoregressions. Modeling, Statistical Inference and Application to Business Cycle Analysis, Lecture Notes in Economics and Mathematical Systems, Volume 454, Berlin.

Manasse, Paulo, Nouriel Roubini, and Axel Schimmelpfennig, 2003. "Predicting Sovereign Debt Crises", IMF WP/03/221, International Monetary Fund, Washington DC.

Mendoza, Enrique, 2001. "The benefits of Dollarization when Stabilization is not Credible and Financial markets are Imperfect," Journal of Money, Credit, and Banking, Vol. 33, №. 2, pp. 440-474.

Owyang, Michael T. and Garey Ramey, 2004. "Regime switching and monetary policy measurement," Journal of Monetary Economics, Volume 51, Issue 8, pp. 1577-1597.

Reinhart, Carmen M., 2000. "The Mirage of Floating Exchange Rates," The American Economic Review, Vol. 90, No. 2, Papers and Proceedings of the One Hundred Twelfth Annual Meeting of the American Economic Association (May, 2000), pp. 65-70.

Van Wijnbergen, Sweder, 1991. "Fiscal Deficits, Exchange Rate Crises, and Inflation," Review of Economic Studies, Vol. 58, No. 1, pp. 81-92.

Weymark, Diana N., 1995. "Estimating exchange market pressure and the degree of exchange market intervention for Canada," Journal of International Economics, Volume 39, Issues 3-4, pp. 273-295. 


\section{Appendix 1}

\section{Regime dates for the full sample}

\begin{tabular}{|c|c|c|c|c|}
\hline & \multicolumn{2}{|c|}{$\mathrm{PRI}^{2}$ (monthly data) } & \multicolumn{2}{|c|}{$\mathrm{PRI}^{1}$ (quarterly data) } \\
\hline & Fixed & Floating & Fixed & Floating \\
\hline Argentina & 1993:2 - 2001:12 [0.9999] & $\begin{array}{l}1985: 1 \text { - 1993:1 [1.0000] } \\
2002: 1 \text { - 2004:10[1.0000] }\end{array}$ & $\begin{array}{l}1985: 3-1985: 4[0.9980] \\
1991: 3-1992: 3[0.9950] \\
1993: 1-1993: 4[0.9969] \\
1994: 3-2001: 3[0.9994] \\
2004: 1-2004: 1[0.5208]\end{array}$ & $\begin{array}{l}1985: 1-1985: 2[1.0000] \\
1986: 1-1991: 2[1.0000] \\
1992: 4-1992: 4[1.0000] \\
1994: 1-1994: 2[1.0000] \\
2001: 4-2003: 4[1.0000] \\
2004: 2-2004: 2[1.0000]\end{array}$ \\
\hline Australia & $\begin{array}{l}1985: 7-1985: 10[0.9843] \\
1990: 5-1990: 10[0.9678] \\
1994: 6-1996: 6[0.9756] \\
2000: 10-2002: 1[0.9762] \\
2002: 10-2004: 10[0.9885]\end{array}$ & $\begin{array}{l}1985: 1 \text { - 1985:6 [0.9061] } \\
1985: 11 \text { - 1990:4[0.9858] } \\
\text { 1990:11 - 1994:5[0.9815] } \\
\text { 1996:7 - 2000:9 [0.9821] } \\
2002: 2 \text { - 2002:9 [0.9654] }\end{array}$ & 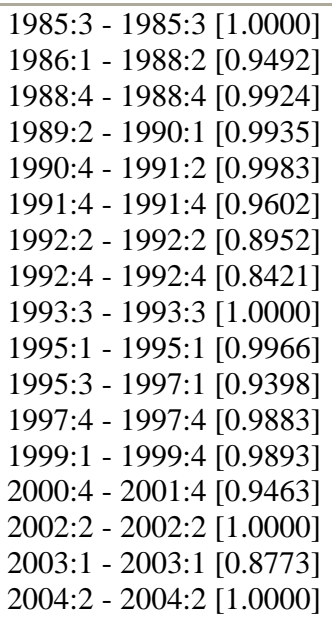 & $\begin{array}{l}1985: 1-1985: 2[0.7893] \\
1985: 4-1985: 4[0.6929] \\
1988: 3-1988: 3[0.9898] \\
1989: 1-1989: 1[0.5051] \\
1990: 2-1990: 3[0.9930] \\
1991: 3-1991: 3[0.9543] \\
1992: 1-1992: 1[0.5174] \\
1992: 3-1992: 3[0.9702] \\
1993: 1-1993: 2[0.9720] \\
1993: 4-1994: 4[0.9158] \\
1995: 2-1995: 2[0.9950] \\
1997: 2-1997: 3[0.9448] \\
1998: 1-1998: 4[0.9020] \\
2000: 1-2000: 3[0.8077] \\
2002: 1-2002: 1[0.5012] \\
2002: 3-2002: 4[0.8428] \\
2003: 2-2004: 1[0.9379]\end{array}$ \\
\hline Brazil & $\begin{array}{l}1987: 9-1992: 1[0.9972] \\
1993: 8-1996: 2[0.9929] \\
2002: 11-2003: 7[0.9825]\end{array}$ & $\begin{array}{l}1985: 1 \text { - 1987:8 [0.9850] } \\
1992: 2 \text { - 1993:7 [0.9664] } \\
\text { 1996:3 - 2002:10[0.9922] } \\
2003: 8 \text { - 2004:10[0.9641] }\end{array}$ & $\begin{array}{l}1986: 2-1986: 4[0.9021] \\
1994: 3-1998: 3[0.9642] \\
1999: 1-1999: 1[0.7019] \\
1999: 3-2000: 2[0.9795] \\
2001: 3 \text { - 2001:3 [0.7495] } \\
2003: 2 \text { - 2003:4 [0.9858] }\end{array}$ & $\begin{array}{l}1985: 1-1986: 1[0.9999] \\
1987: 1-1994: 2[0.9899] \\
1998: 4-1998: 4[0.9816] \\
1999: 2-1999: 2[1.0000] \\
2000: 3-2001: 2[0.9909] \\
2001: 4-2003: 1[0.9710] \\
2004: 1-2004: 2[1.0000]\end{array}$ \\
\hline Chile & $\begin{array}{l}\text { 1985:1 - 1985:5 [0.9778] } \\
\text { 1986:1 - 1987:7 [0.9841] } \\
\text { 1989:1 - 1994:3 [0.9955] } \\
1994: 11 \text { - 2000:2 [0.9920] }\end{array}$ & $\begin{array}{l}1985: 6 \text { - 1985:12[0.8944] } \\
\text { 1987:8 - 1988:12[0.9523] } \\
\text { 1994:4 - 1994:10[0.8550] } \\
2000: 3 \text { - 2004:10[0.9918] }\end{array}$ & $\begin{array}{l}1985: 3-1985: 4[0.9690] \\
1986: 2-1987: 1[0.9290] \\
1987: 4-1989: 2[0.9102] \\
1990: 1-1990: 2[0.9806] \\
1991: 3 \text { - 1991:3 [0.6312] } \\
1992: 1-1992: 1[0.9851] \\
1992: 3 \text { - 1992:3 [0.9270] } \\
1994: 1-1994: 4[0.9278] \\
1996: 1-1997: 2[0.9896] \\
1998: 1-1998: 3[0.8825] \\
1999: 1-1999: 1[0.9956] \\
2000: 1-2000: 1[0.9468] \\
2000: 4-2000: 4[0.8708] \\
2004: 2-2004: 2[0.5828]\end{array}$ & $\begin{array}{l}1985: 1-1985: 2[0.9362] \\
1986: 1-1986: 1[0.9994] \\
1987: 2-1987: 3[0.7515] \\
1989: 3-1989: 4[0.9975] \\
1990: 3-1991: 2[0.7152] \\
1991: 4-1991: 4[0.9822] \\
1992: 2-1992: 2[0.9896] \\
1992: 4-1993: 4[0.9620] \\
1995: 1-1995: 4[0.9200] \\
1997: 3-1997: 4[0.7751] \\
1998: 4-1998: 4[0.9767] \\
1999: 2-1999: 4[0.9968] \\
2000: 2-2000: 3[0.9709] \\
2001: 1-2004: 1[0.9460]\end{array}$ \\
\hline
\end{tabular}

Note: Numbers in square bracket are regime probabilities 


\section{Table A1 (continued): Regime dates for the full sample}

\begin{tabular}{|c|c|c|c|c|}
\hline & \multicolumn{2}{|c|}{$\mathrm{PRI}^{2}$ (monthly data) } & \multicolumn{2}{|c|}{$\mathrm{PRI}^{1}$ (quarterly data) } \\
\hline & Fixed & Floating & Fixed & Floating \\
\hline Colombia & $\begin{array}{l}1985: 1 \text { - 1988:4 [0.9813] } \\
1990: 1 \text { - 1993:12 [0.9846] } \\
\text { 1997:1 - 1999:9 [0.9787] } \\
2001: 8 \text { - 2002:10 [0.9577] }\end{array}$ & $\begin{array}{l}1988: 5 \text { - 1989:12[0.9407] } \\
\text { 1994:1 - 1996:12[0.9942] } \\
\text { 1999:10 - 2001:7[0.9656] } \\
2002: 11-2004: 10[0.9971]\end{array}$ & $\begin{array}{l}1985: 1-1985: 1[0.7466] \\
1985: 3-1985: 4[0.8305] \\
1986: 3-1986: 3[1.0000] \\
1987: 1-1987: 1[0.9869] \\
1987: 3-1987: 3[0.9970] \\
1988: 1-1988: 2[1.0000] \\
1988: 4-1989: 3[0.9191] \\
1991: 1-1991: 2[0.9999] \\
1991: 4-1992: 1[0.8683] \\
1992: 3-1992: 3[0.9995] \\
1993: 2-1993: 3[0.9138] \\
1994: 2-1995: 3[0.9205] \\
1996: 2-1997: 1[0.9967] \\
1998: 1 \text { - 1998:2 [0.9940] } \\
1998: 4-1998: 4[1.0000] \\
1999: 4-1999: 4[1.0000] \\
2000: 3-2000: 3[1.0000] \\
2001: 3-2001: 4[0.9795] \\
2003: 1-2003: 3[0.9819] \\
2004: 1-2004: 2[0.8890\end{array}$ & $\begin{array}{l}1985: 2-1985: 2[0.8233] \\
1986: 1-1986: 2[0.8246] \\
1986: 4-1986: 4[0.7985] \\
1987: 2-1987: 2[0.8904] \\
1987: 4-1987: 4[0.8795] \\
1988: 3-1988: 3[0.8603] \\
1989: 4-1990: 4[0.8279] \\
1991: 3-1991: 3[0.8352] \\
1992: 2-1992: 2[0.6448] \\
1992: 4-1993: 1[0.7998] \\
1993: 4-1994: 1[0.8615] \\
1995: 4-1996: 1[0.8527] \\
1997: 2-1997: 4[0.8660] \\
1998: 3-1998: 3[0.5796] \\
1999: 1-1999: 3[0.7848] \\
2000: 1-2000: 2[0.6589] \\
2000: 4-2001: 2[0.7643] \\
2002: 1-2002: 4[0.8020] \\
2003: 4-2003: 4[0.7382]\end{array}$ \\
\hline Germany & $\begin{array}{l}1985: 1-1995: 8[0.9970] \\
1996: 10-2000: 11[0.9779] \\
2001: 5-2002: 11[0.9655]\end{array}$ & $\begin{array}{l}1995: 9-1996: 9[0.9850] \\
2000: 12-2001: 4[0.9882] \\
2002: 12-2004: 10[0.9894]\end{array}$ & $\begin{array}{l}1986: 3-1989: 3[0.9016] \\
1990: 4-1993: 3[0.9556] \\
1994: 3-1996: 3[0.8208]\end{array}$ & $\begin{array}{l}1985: 1-1986: 2[0.8588] \\
1989: 4-1990: 3[0.8491] \\
1993: 4-1994: 2[0.5993] \\
1996: 4-1998: 1[0.8565] \\
1999: 1-2001: 2[0.9002] \\
2002: 4-2004: 1[0.8131]\end{array}$ \\
\hline Indonesia & $\begin{array}{l}1985: 1-1986: 8[0.9975] \\
1988: 9-1994: 3[0.9972] \\
1995: 6-1997: 10[0.9769]\end{array}$ & $\begin{array}{l}1986: 9-1988: 8 \text { [1.0000] } \\
1994: 4-1995: 5[0.9688] \\
1997: 11-2004: 10[0.9945]\end{array}$ & $\begin{array}{l}1985: 1 \text { - 1986:1 [0.9928] } \\
1986: 4-1993: 3 \text { [0.9927] } \\
\text { 1994:1 - 1997:1 [0.9959] } \\
2002: 2 \text { - 2002:3 [0.8955] } \\
2003: 3 \text { - 2003:4 [0.9597] }\end{array}$ & $\begin{array}{l}1986: 2-1986: 3[0.9999] \\
1993: 4-1993: 4[1.0000] \\
1997: 2-2002: 1[0.9794] \\
2002: 4-2003: 2[0.8464] \\
2004: 1-2004: 2[0.7716]\end{array}$ \\
\hline India & $\begin{array}{l}1985: 12-1987: 1[0.9687] \\
1990: 10-1995: 12[0.9824] \\
1997: 4-2000: 8[0.9896] \\
2001: 7-2004: 10[0.9866]\end{array}$ & $\begin{array}{l}1985: 1 \text { - 1985:11[0.9796] } \\
1987: 2 \text { - 1990:9 [0.9826] } \\
\text { 1996:1 - 1997:3 [0.9933] } \\
2000: 9 \text { - 2001:6 [0.9321] }\end{array}$ & $\begin{array}{l}1991: 3-1992: 2[0.9853] \\
1993: 2-1994: 3[0.9890] \\
1995: 1-1995: 1[0.6559] \\
1996: 3-1997: 1[0.9271] \\
1998: 4-1998: 4[0.7074] \\
1999: 3-1999: 4[0.7056\end{array}$ & $\begin{array}{l}1985: 1-1991: 2[0.9921] \\
1992: 3-1993: 1[0.9998] \\
1994: 4-1994: 4[1.0000] \\
1995: 2-1996: 2[1.0000] \\
1997: 2-1998: 3[1.0000] \\
1999: 1-1999: 2[1.0000] \\
2000: 1-2004: 2[0.9955\end{array}$ \\
\hline
\end{tabular}

Note: Numbers in square bracket are regime probabilities 


\section{Table A1 (continued): Regime dates for the full sample}

\begin{tabular}{|c|c|c|c|c|}
\hline & \multicolumn{2}{|c|}{$\mathrm{PRI}^{2}$ (monthly data) } & \multicolumn{2}{|c|}{$\mathrm{PRI}^{1}$ (quarterly data) } \\
\hline & Fixed & Floating & Fixed & Floating \\
\hline Japan & & & $\begin{array}{l}\text { 1986:4 - 1987:2 [0.8451] } \\
\text { 1987:4 - 1988:1 [0.7933] } \\
\text { 1989:1 - 1989:4 [0.9582] } \\
\text { 1990:4 - 1990:4 [0.6772] } \\
\text { 1991:2 - 1991:2 [0.8616] } \\
\text { 1992:3 - 1992:3 [0.9196] } \\
\text { 1993:2 - 1993:2 [0.6899] } \\
\text { 1993:4 - 1994:1 [0.8319] } \\
\text { 1994:3 - 1994:3 [0.9941] } \\
\text { 1995:4 - 1996:4 [0.7367] } \\
\text { 1998:4 - 1999:1 [0.8322] } \\
\text { 1999:4 - 2000:2 [0.9504] } \\
2001: 2-2001: 2[0.8958] \\
2003: 1-2003: 2[0.9936] \\
2003: 4-2003: 4[0.9885] \\
2004: 2-2004: 2[0.9906]\end{array}$ & $\begin{array}{l}1985: 1-1986: 3[0.8250] \\
1987: 3-1987: 3[0.7812] \\
1988: 2-1988: 4[0.8571] \\
1990: 1-1990: 3[0.9932] \\
1991: 1-1991: 1[0.6927] \\
1991: 3-1992: 2[0.9688] \\
1992: 4-1993: 1[0.7376] \\
1993: 3-1993: 3[0.9456] \\
1994: 2-1994: 2[0.7494] \\
1994: 4-1995: 3[0.8267] \\
1997: 1-1998: 3[0.8161] \\
1999: 2-1999: 3[0.7780] \\
2000: 3-2001: 1[0.8417] \\
2001: 3-2002: 4[0.9586] \\
2003: 3-2003: 3[0.8644] \\
2004: 1-2004: 1[0.7316\end{array}$ \\
\hline Korea & $\begin{array}{l}1985: 1 \text { - 1987:8 [0.9960] } \\
\text { 1988:5 - 1990:11 [0.9754] } \\
\text { 1991:6 - 1996:12 [0.9715] } \\
1998: 10 \text { - 2000:7 [0.9544] }\end{array}$ & $\begin{array}{l}1987: 9 \text { - 1988:4 [0.9565] } \\
1990: 12 \text { - 1991:5[0.8360] } \\
\text { 1997:1 - 1998:9 [0.9632] } \\
2000: 8 \text { - 2004:10[0.9956] }\end{array}$ & $\begin{array}{l}1985: 1-1986: 3[0.9800] \\
1987: 4-1988: 2[0.9776] \\
1988: 4-1988: 4[0.6535] \\
1989: 2-1989: 4[0.9618] \\
1990: 2-1991: 2[0.9809] \\
1992: 2-1993: 3[0.8691] \\
1994: 1-1994: 4[0.9460] \\
1995: 2-1996: 1[0.9165] \\
1996: 3-1996: 3[0.6818] \\
1997: 1-1997: 2[0.9534] \\
1999: 1-2000: 2[0.9765] \\
2001: 3-2001: 3[0.8266] \\
2003: 1-2003: 1[0.7939] \\
2003: 3-2004: 2[0.9777]\end{array}$ & $\begin{array}{l}1986: 4-1987: 3[0.9623] \\
1988: 3-1988: 3[0.9999] \\
1989: 1-1989: 1[0.7344] \\
1990: 1-1990: 1[0.9934] \\
1991: 3-1992: 1[0.9283] \\
1993: 4-1993: 4[0.9987] \\
1995: 1-1995: 1[0.9571] \\
1996: 2-1996: 2[0.9931] \\
1996: 4-1996: 4[1.0000] \\
1997: 3-1998: 4[0.9754] \\
2000: 3-2001: 2[0.9999] \\
2001: 4-2002: 4[0.9421] \\
2003: 2-2003: 2[0.6636]\end{array}$ \\
\hline Mexico & $\begin{array}{l}1985: 1 \text { - 1985:7 [0.9652] } \\
1989: 7 \text { - 1994:12 [0.9925] } \\
1997: 1 \text { - 1999:6 [0.9738] } \\
2001: 3 \text { - 2002:10 [0.9873] }\end{array}$ & $\begin{array}{l}\text { 1985:8 - 1989:6 [0.9969] } \\
\text { 1995:1 - 1996:12[0.9983] } \\
\text { 1999:7 - 2001:2 [0.9939] } \\
\text { 2002:11-2004:10[0.9960] }\end{array}$ & $\begin{array}{l}1985: 1 \text { - 1987:4 [0.9990] } \\
1988: 4-1989: 1[0.7359] \\
1992: 1 \text { - 1992:1 [0.9317] } \\
1993: 4-1994: 2[0.8463] \\
1994: 4-1994: 4[1.0000] \\
1995: 3-1996: 1[0.9156] \\
1997: 3-1999: 3[0.9863] \\
2000: 1 \text { - 2001:2 [0.9126] } \\
2001: 4-2004: 2[0.9369]\end{array}$ & $\begin{array}{l}1988: 1-1988: 3[0.9233] \\
1989: 2-1991: 4[0.9404] \\
1992: 2-1993: 3[0.9887] \\
1994: 3-1994: 3[0.7145] \\
1995: 1-1995: 2[0.9223] \\
1996: 2-1997: 2[0.9625] \\
1999: 4-1999: 4[0.8061] \\
2001: 3-2001: 3[0.6187]\end{array}$ \\
\hline Malaysia & $\begin{array}{l}1985: 12-1987: 3[0.9463] \\
1990: 2-1995: 1[0.9820] \\
2000: 9-2004: 10[0.9994]\end{array}$ & $\begin{array}{l}1985: 1-1985: 11[0.9799] \\
1987: 4-1990: 1[0.9908] \\
1995: 2-2000: 8 \text { [0.9871] }\end{array}$ & $1998: 4$ - 2004:2 [0.9887] & $1985: 1$ - 1998:3 [0.9993] \\
\hline
\end{tabular}

Note: Numbers in square bracket are regime probabilities 


\section{Table A1 (continued): Regime dates for the full sample}

\begin{tabular}{|c|c|c|c|c|}
\hline & \multicolumn{2}{|c|}{$\mathrm{PRI}^{2}$ (monthly data) } & \multicolumn{2}{|c|}{$\mathrm{PRI}^{1}$ (quarterly data) } \\
\hline & Fixed & Floating & Fixed & Floating \\
\hline New Zealand & $\begin{array}{l}1985: 1 \text { - 1987:12 [0.9942] } \\
\text { 1989:3 - 1994:6 [0.9930] } \\
\text { 1996:8 - 1998:12 [0.9807] } \\
2002: 1 \text { - 2002:7 [0.9020] }\end{array}$ & $\begin{array}{l}\text { 1988:1 - 1989:2 [0.9381] } \\
\text { 1994:7 - 1996:7 [0.9681] } \\
\text { 1999:1 - 2001:12[0.9898] } \\
\text { 2002:8 - 2004:10[0.9864] }\end{array}$ & $\begin{array}{l}1985: 1 \text { - 1985:1 [1.0000] } \\
\text { 1985:4 - 1985:4 [0.9882] } \\
\text { 1986:2 - 1986:3 [0.9994] } \\
\text { 1987:2 - 1988:4 [0.9095] } \\
\text { 1989:2 - 1989:4 [1.0000] } \\
\text { 1990:2 - 1992:4 [0.9909] } \\
\text { 1993:2 - 1994:3 [0.9254] } \\
\text { 1995:1 - 1997:1 [0.9505] } \\
\text { 1998:3 - 2000:1 [0.9168] } \\
2000: 4-2000: 4[0.6318] \\
2001: 4-2001: 4 \text { [1.0000] } \\
2002: 2-2002: 3[0.9910] \\
2003: 1-2004: 2 \text { [0.9585] }\end{array}$ & $\begin{array}{l}1985: 2-1985: 3[0.8013] \\
1986: 1-1986: 1[0.6634] \\
1986: 4-1987: 1[0.7880] \\
1989: 1-1989: 1[0.8925] \\
1990: 1-1990: 1[0.5151] \\
1993: 1-1993: 1[0.7945] \\
1994: 4-1994: 4[0.8737] \\
1997: 2-1998: 2[0.8922] \\
2000: 2-2000: 3[0.9664] \\
2001: 1-2001: 3[0.8782] \\
2002: 1-2002: 1[0.8813] \\
2002: 4-2002: 4[0.8973]\end{array}$ \\
\hline Thailand & $1986: 3$ - 1997:6 [0.9985] & $\begin{array}{l}1985: 1 \text { - 1986:2 [0.9743] } \\
1997: 7 \text { - 2004:10[1.0000] }\end{array}$ & $\begin{array}{l}1985: 1-1985: 1[0.8755] \\
1985: 3-1987: 2 \text { [0.9712] } \\
\text { 1987:4 - 1990:1 [0.9899] } \\
\text { 1990:4 - 1991:2 [0.9788] } \\
\text { 1991:4 - 1992:1 [0.9645] } \\
\text { 1992:3 - 1997:1 [0.9765] } \\
1998: 4-1999: 1[0.9629]\end{array}$ & $\begin{array}{l}1985: 2-1985: 2[1.0000] \\
1987: 3-1987: 3[0.7010] \\
1990: 2-1990: 3[0.9874] \\
1991: 3-1991: 3[0.9999] \\
1992: 2-1992: 2[0.9969] \\
1997: 2-1998: 3[1.0000] \\
1999: 2-2004: 2[0.9664]\end{array}$ \\
\hline Venezuela & $\begin{array}{l}1985: 1-1987: 1[0.9736] \\
1988: 11-1989: 2[0.9564] \\
1990: 11-1993: 6[0.9666] \\
1997: 3-2000: 5[0.9774] \\
2001: 3-2002: 10[0.9482] \\
2004: 1-2004: 10[0.8445]\end{array}$ & $\begin{array}{l}1987: 2 \text { - 1988:10[0.9812] } \\
1989: 3 \text { - 1990:10[0.9893] } \\
\text { 1993:7 - 1997:2 [0.9937] } \\
2000: 6 \text { - 2001:2 [0.9112] } \\
2002: 11-2003: 12[0.9685]\end{array}$ & $\begin{array}{l}1985: 1 \text { - 1986:2 [0.9910] } \\
1987: 1-1988: 3[0.9886] \\
1989: 2-1989: 2[0.7395] \\
1990: 3-1990: 3[0.6974] \\
1994: 4-1995: 2[0.9770] \\
1996: 3-1997: 4[0.8577] \\
1998: 3-1998: 4[0.9299] \\
2000: 2-2001: 2[0.8947] \\
2003: 1-2003: 3[0.9590] \\
2004: 2-2004: 2[0.8974]\end{array}$ & $\begin{array}{l}1986: 3-1986: 4[1.0000] \\
1988: 4-1989: 1[1.0000] \\
1989: 3-1990: 2[1.0000] \\
1990: 4-1994: 3[0.9953] \\
1995: 3-1996: 2[0.9655] \\
1998: 1-1998: 2[0.7924] \\
1999: 1-2000: 1[0.8531] \\
2001: 3-2002: 4[0.9935] \\
2003: 4-2004: 1[1.0000\end{array}$ \\
\hline
\end{tabular}

Note: Numbers in square bracket are regime probabilities 


\section{Appendix 2: Plot analysis for full sample}
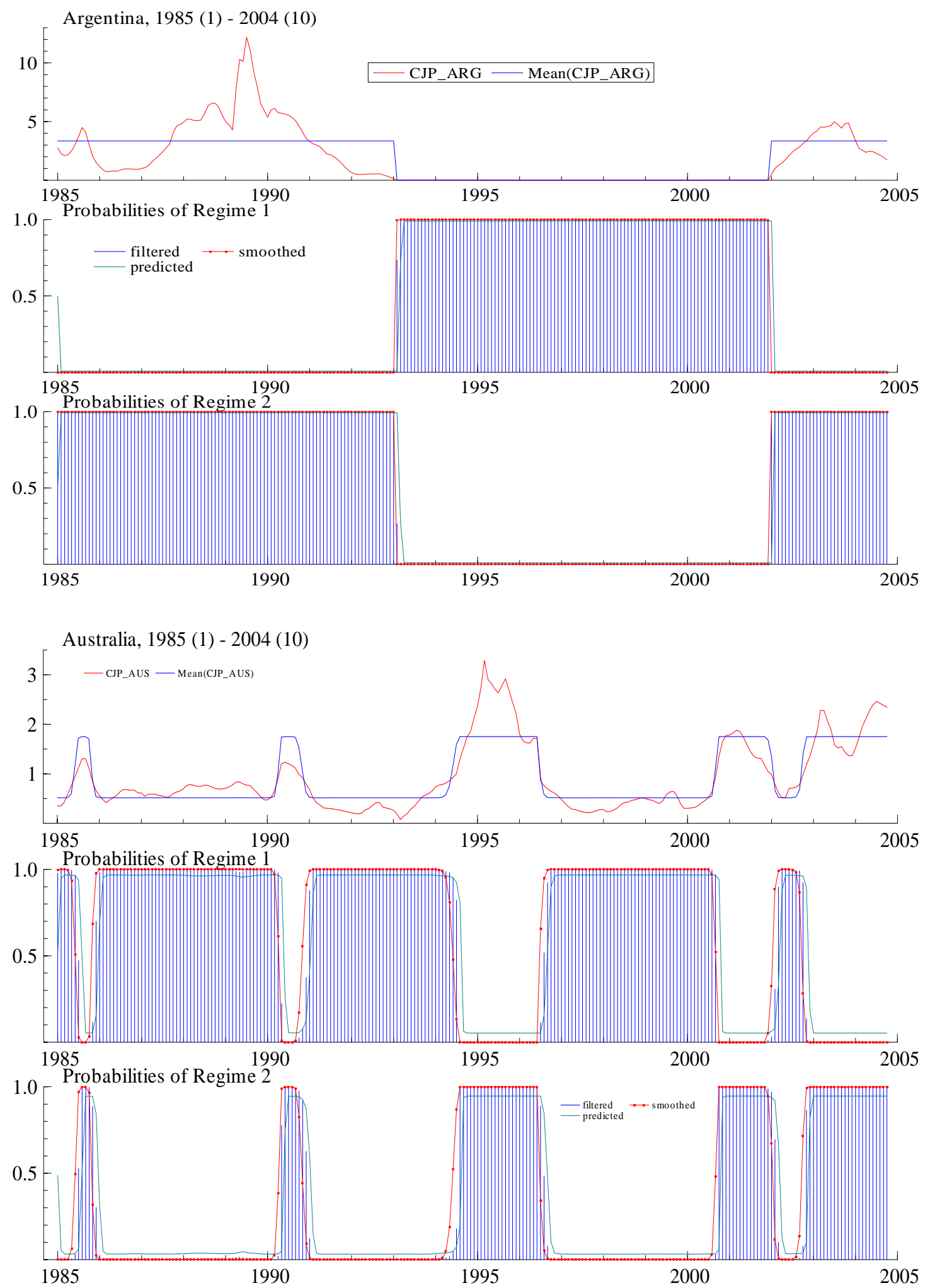

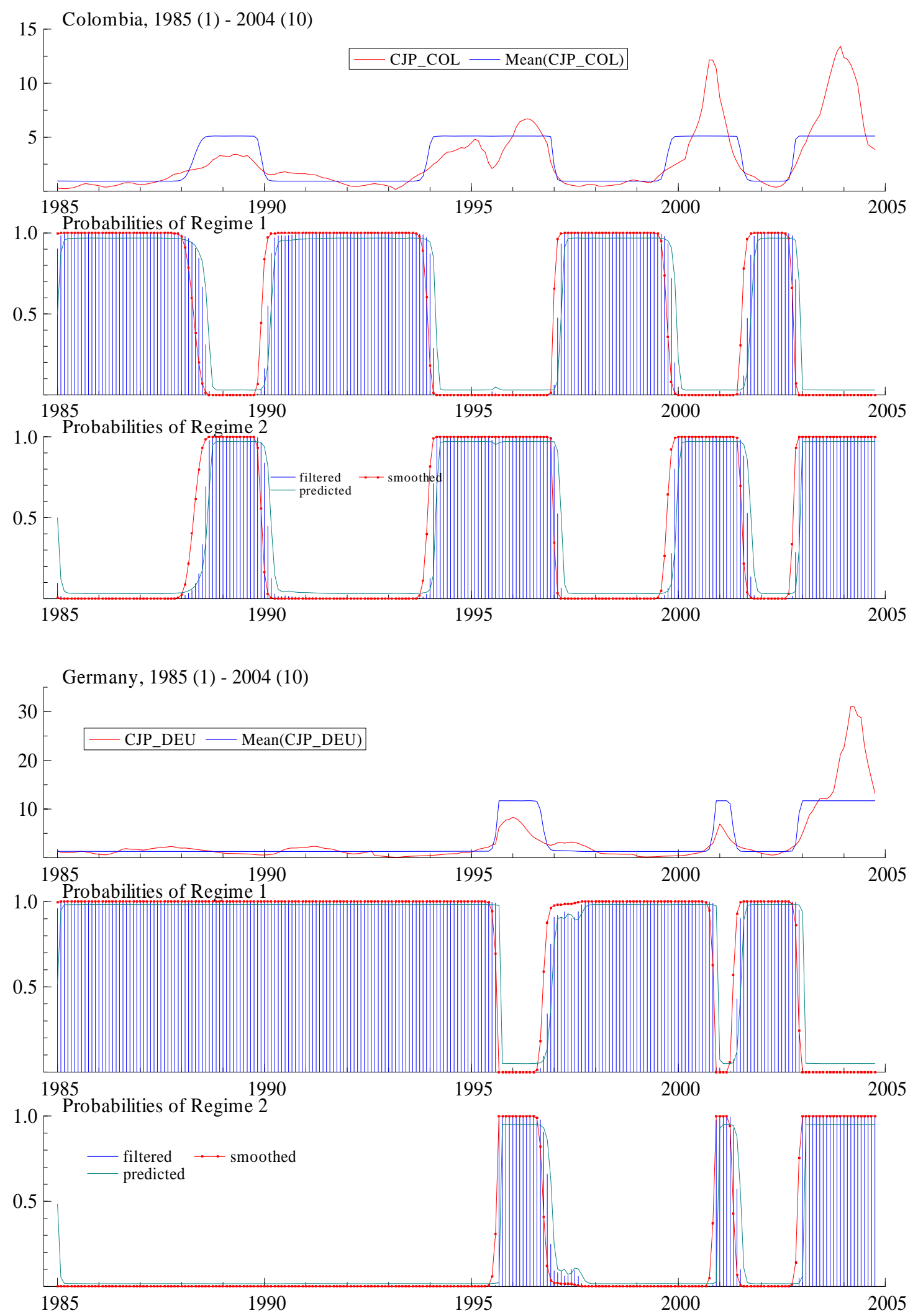

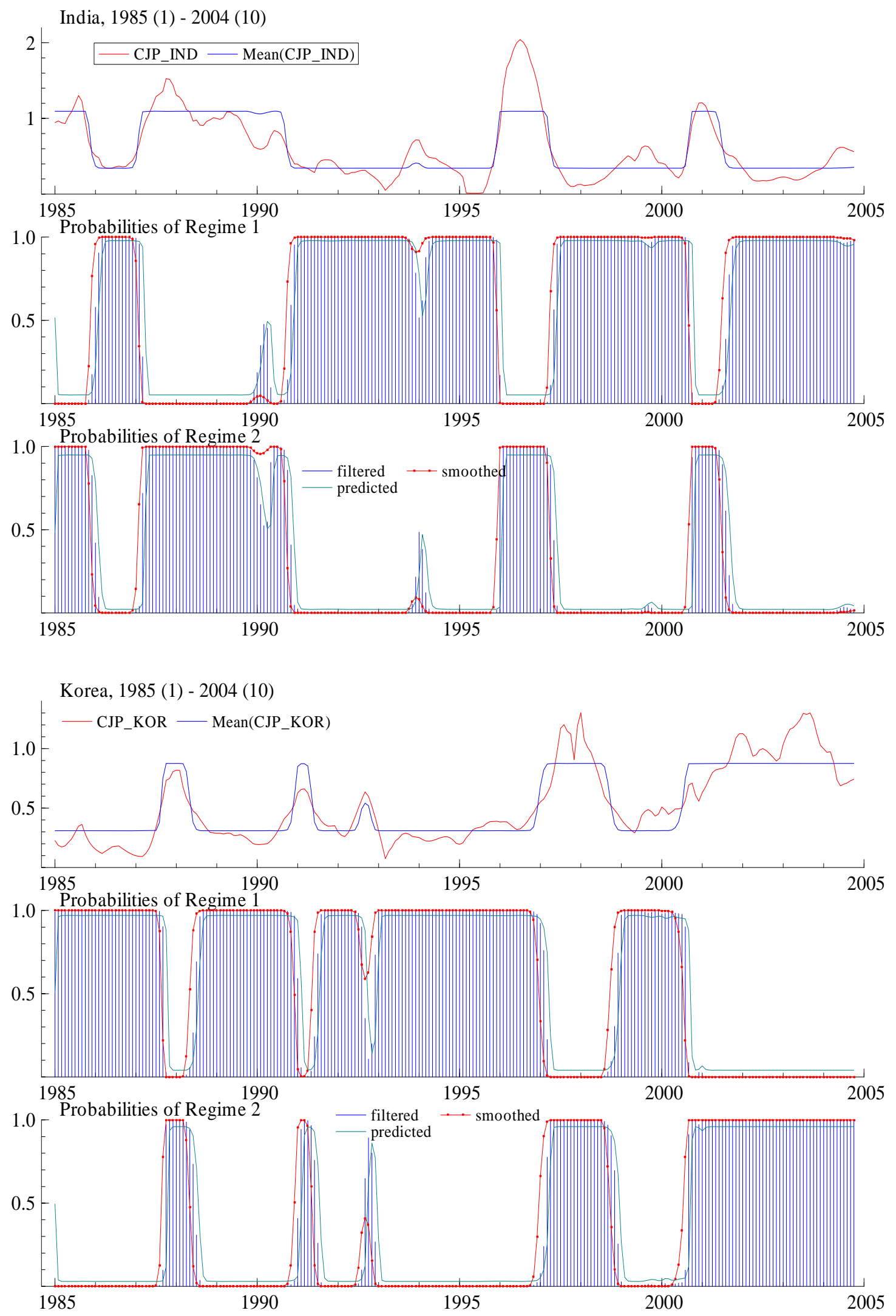

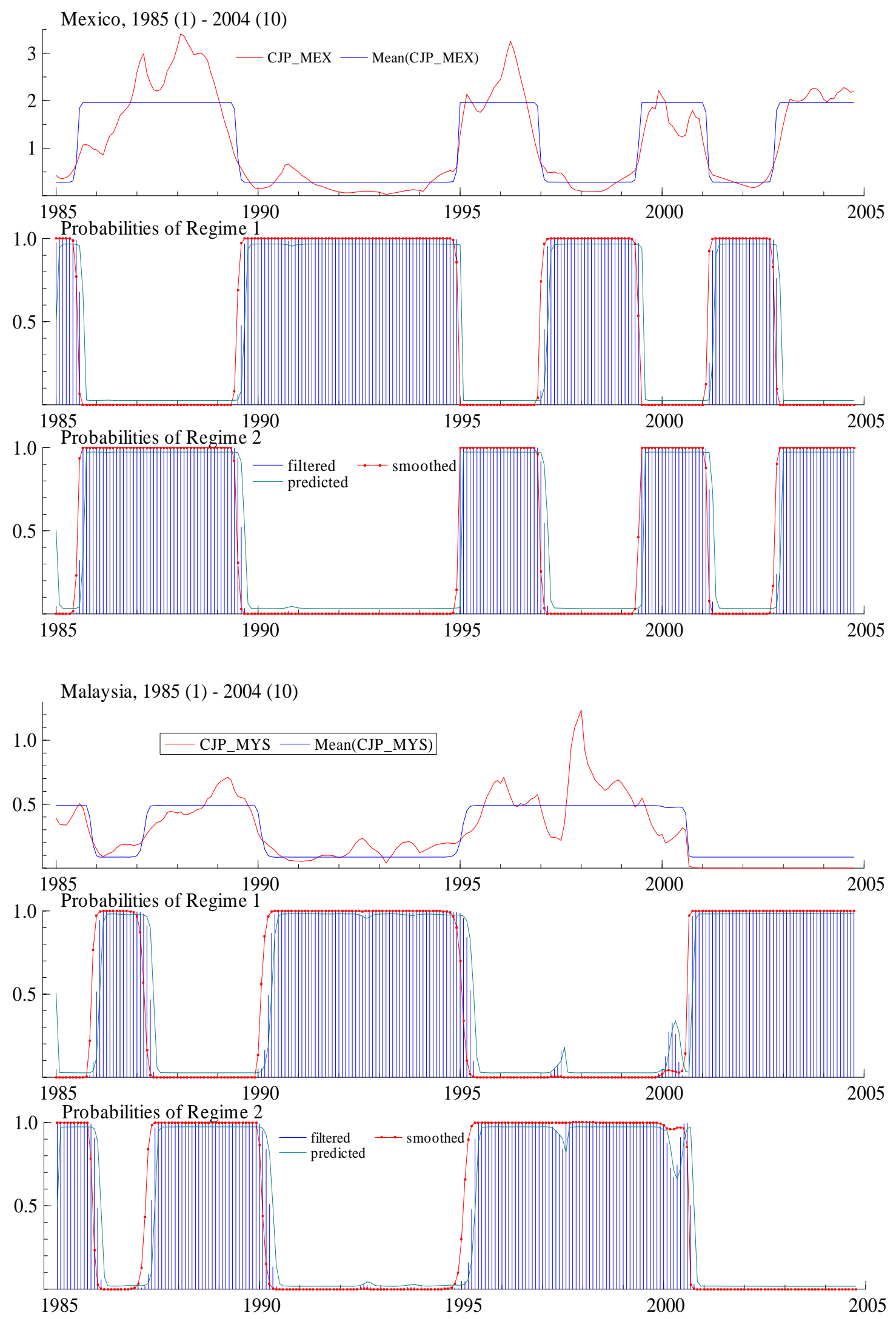

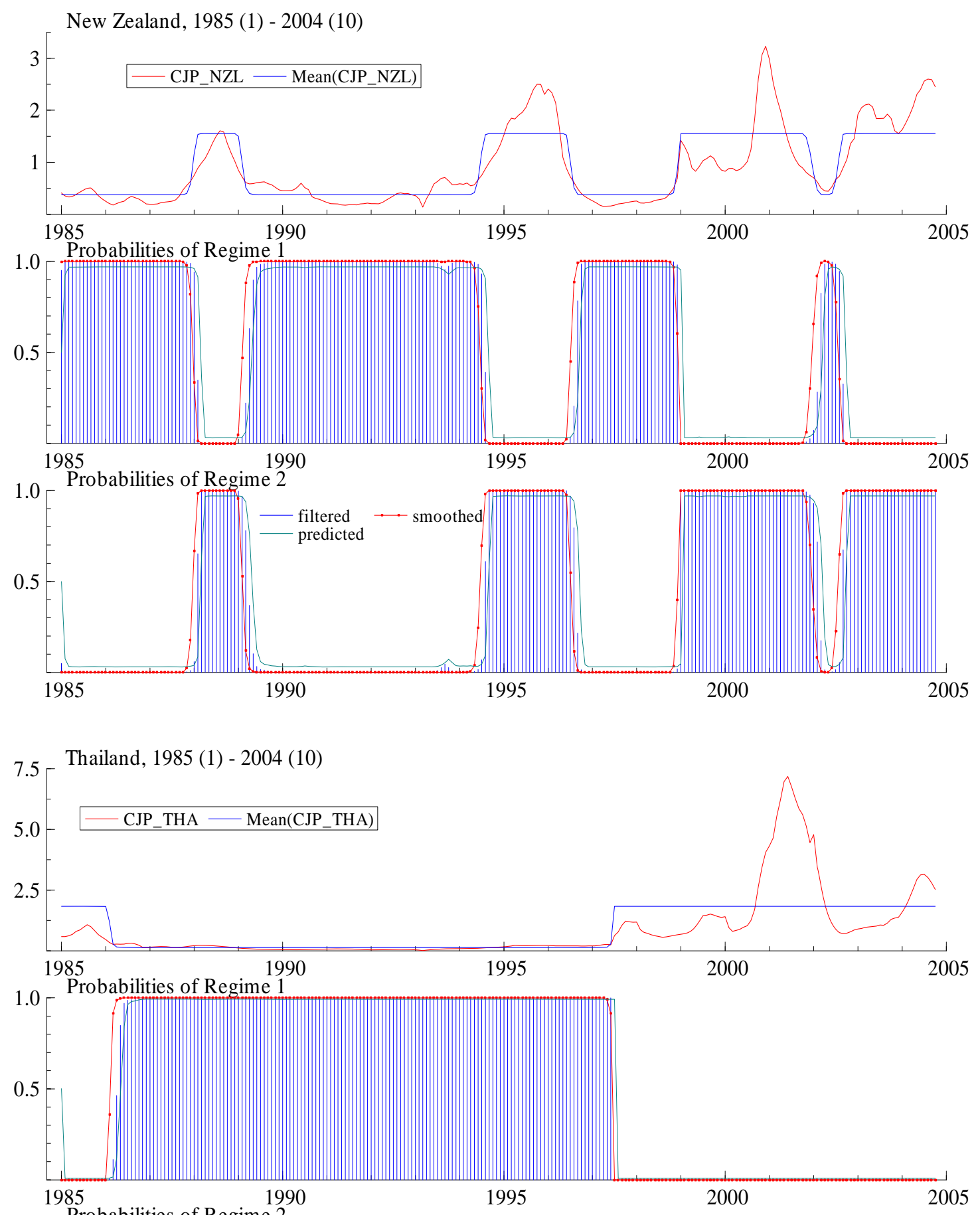

1.0 Probabilities of Regime 2

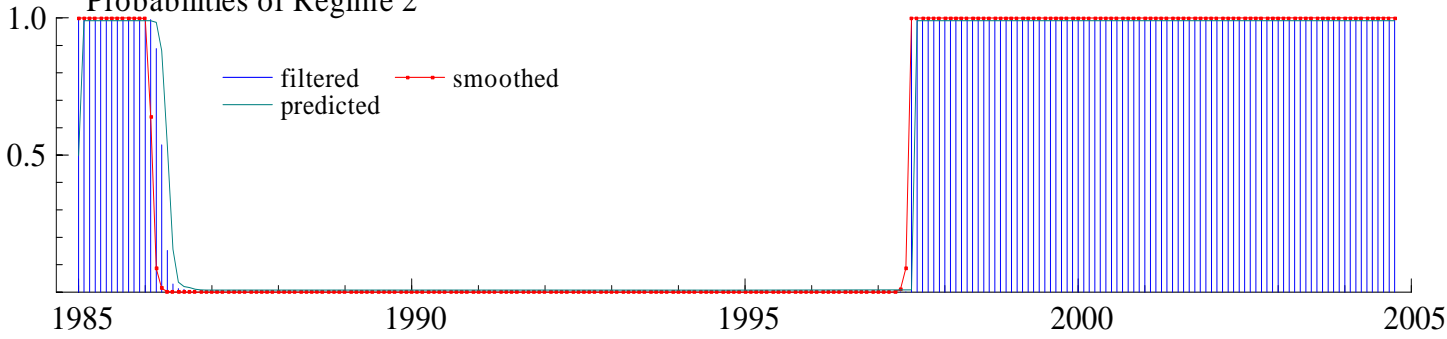



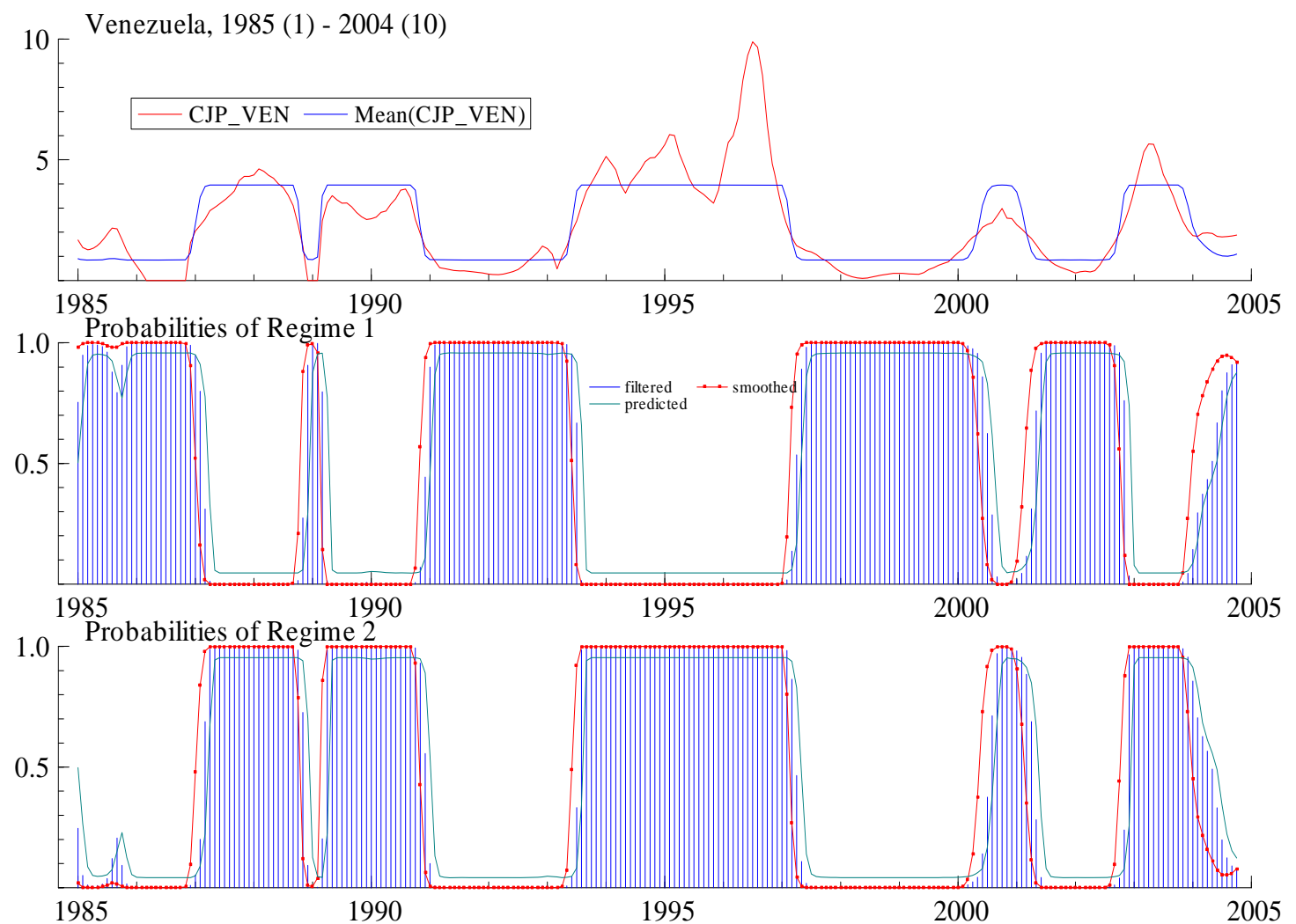
Appendix 3: Country-wise Descriptive Statistics

\begin{tabular}{|c|c|c|c|c|c|c|c|c|c|c|c|c|c|c|}
\hline & Argentina & Australia & Brazil & Chile & Colombia & Germany & Indonesia & India & Korea & Malaysia & Mexico & New Zealand & Thailand & Venezuela \\
\hline \multicolumn{15}{|c|}{ Debt/asset ratio } \\
\hline fixed & 0.62 & 3.52 & 1.25 & 2.51 & 2.5 & 0.74 & 5.24 & 6.19 & 3.02 & 2.68 & 0.85 & 3.21 & 2.18 & 1.41 \\
\hline pre-float & 0.70 & 2.94 & 4.64 & 3.47 & 1.64 & 0.9 & 4.03 & 4.82 & 2.04 & 2.07 & 1.11 & 2.37 & 2.25 & 1.47 \\
\hline post-float & 0.54 & 2.69 & 2.55 & 3.93 & 1.46 & 0.91 & 4.61 & 3.95 & 1.34 & 1.85 & 1.28 & 2.39 & 2.12 & 1.45 \\
\hline float & 6.91 & 2.53 & 2.49 & 1.77 & 1.24 & 0.81 & 2.2 & 9.26 & 0.44 & 3.27 & 1.37 & 2.15 & 1.49 & 2.09 \\
\hline \multicolumn{15}{|c|}{ GDP growth } \\
\hline fixed & 0 & 0.03 & -0.04 & 0.08 & 0 & 0.03 & 0.07 & 0.06 & 0.16 & 0.11 & 0.07 & -0.04 & 0.11 & 0. \\
\hline pre-float & -0.96 & -0.01 & -0.03 & 0.07 & -0.09 & -0.01 & -0.32 & -0.01 & 0.05 & -0.09 & 0.13 & 0.1 & -0.45 & -0.3 \\
\hline post-float & -0.08 & 0 & -0.03 & -0.02 & -0.14 & 0.01 & 0.06 & 0.03 & 0.11 & 0.01 & 0.13 & -0.05 & 0.02 & -0.6 \\
\hline float & 0.17 & 0.13 & 0.08 & 0.03 & 0.06 & -0.01 & 0.1 & 0.07 & -0.05 & 0.03 & -0.03 & 0.07 & 0.02 & 0.17 \\
\hline \multicolumn{15}{|c|}{ Stock market volatility } \\
\hline fixed & 0.47 & 0.19 & 0.84 & 0.45 & & 0.41 & 0.67 & 0.64 & 0.53 & 0.67 & 0.38 & 0.32 & 0.6 & 0.71 \\
\hline pre-float & 0.59 & 0.23 & 1.39 & 0.34 & 0.31 & 0.45 & 0.41 & 0.42 & 0.46 & 0.58 & 0.62 & 0.37 & 0.52 & 0.43 \\
\hline post-float & 1.1 & 0.16 & 2.35 & 0.26 & 0.51 & 0.44 & 0.58 & 0.37 & 0.52 & 0.6 & 0.49 & 0.3 & 0.93 & 0.37 \\
\hline float & 1.9 & 0.18 & 2 & 0.25 & 0.61 & 0.31 & 0.56 & 0.46 & 0.79 & 0.72 & 0.68 & 0.19 & 0.69 & 0.82 \\
\hline \multicolumn{15}{|c|}{ REER change } \\
\hline fixed & 0.58 & -0.22 & -0.38 & 0.24 & 0.19 & 0 & -0.02 & -0.18 & -0.15 & -0.05 & -0.02 & -0.18 & 0 & 0.34 \\
\hline pre-float & 0.77 & -0.12 & -0.64 & 0.26 & 0.2 & -0.12 & -0.32 & -0.23 & -0.2 & 0 & -0.02 & -0.19 & 0.06 & 0.19 \\
\hline post-float & -0.25 & -0.1 & -0.55 & 0.33 & 0.2 & -0.08 & -0.12 & 0.04 & -0.13 & 0.32 & 0.17 & -0.02 & 0.17 & 0.27 \\
\hline float & -0.1 & -0.12 & -0.27 & 0.4 & 0.05 & -0.02 & -0.13 & 0.05 & -0.26 & -0.16 & 0.01 & -0.13 & -0.03 & 0.36 \\
\hline \multicolumn{15}{|c|}{ Change in M0/reserves } \\
\hline fixed & -0.04 & 0.02 & 0.41 & 0.03 & 0.01 & 0.02 & -0.04 & -0.12 & -0.22 & -0.1 & -0.14 & -0.03 & -0.13 & 0.25 \\
\hline pre-float & 0.13 & 0.02 & 1.12 & 0.11 & 0.6 & 0.04 & 0.09 & 0 & 0.04 & 0.34 & -0.04 & -0.14 & 0.11 & 0.32 \\
\hline post-float & 0.85 & -0.01 & 1.33 & 0.04 & 0.2 & 0.01 & 0.37 & -0.08 & -0.09 & 0.16 & 0.03 & 0.15 & 0.36 & 0.31 \\
\hline float & 1.11 & -0.11 & 2.18 & 0.06 & 0.15 & 0.06 & 0.01 & 0.3 & -0.19 & 0.33 & 0.02 & 0.02 & 0 & 0.26 \\
\hline \multicolumn{15}{|c|}{ Change in Inflation Differential } \\
\hline fixed & -0.11 & 0.00 & 0.06 & -0.11 & -0.08 & 0.13 & 0.06 & -0.02 & -0.1 & 0.01 & -0.08 & -0.01 & -0.18 & 0.01 \\
\hline pre-float & -0.01 & 0.01 & 0.15 & 0.13 & -0.02 & 0 & -0.02 & 0.01 & -0.12 & -0.18 & -0.04 & 0.03 & 0 & 0.03 \\
\hline post-float & 0.08 & 0.01 & 0.2 & 0.12 & -0.08 & -0.02 & -0.03 & -0.12 & -0.03 & 0.02 & -0.07 & 0.00 & -0.05 & 0.04 \\
\hline float & 0.15 & -0.01 & 0.44 & -0.05 & 0.1 & -0.04 & 0.01 & 0.35 & -0.01 & 0.03 & -0.08 & -0.00 & -0.03 & 0.1 \\
\hline
\end{tabular}


Appendix 4: Correlations across explanatory variables and capital inflows?:

\begin{tabular}{|c|c|c|c|c|c|c|c|c|}
\hline & $\begin{array}{l}\text { Ln(capital } \\
\text { inflows) }\end{array}$ & $\begin{array}{l}\text { Ln(external } \\
\text { liabilities } \\
\text { assets) }\end{array}$ & $\begin{array}{l}\text { Ln(real } \\
\text { effective } \\
\text { exchange } \\
\text { rate) }\end{array}$ & $\begin{array}{l}\text { Growth in } \\
\text { inflation } \\
\text { difference } \\
\text { (1 yr.) }\end{array}$ & $\begin{array}{l}\text { Growth in } \\
\text { GDP } \\
\text { (1 yr.) }\end{array}$ & $\begin{array}{l}\text { Volatility } \\
\text { in stk. } \\
\text { market } \\
(1 \mathrm{yr} .)\end{array}$ & $\begin{array}{l}\text { Growth in } \\
\text { stk. } \\
\text { market } \\
\text { ( } 6 \text { month) }\end{array}$ & $\begin{array}{l}\text { Growth in } \\
\text { M0 over } \\
\text { reserves }\end{array}$ \\
\hline Ln(capital inflows) & 1.0000 & & & & & & & \\
\hline $\begin{array}{l}\text { Ln(external liabilities } \\
\text { to assets) }\end{array}$ & -0.2950 & 1.0000 & & & & & & \\
\hline P-value & 0.0000 & & & & & & & \\
\hline $\begin{array}{l}\text { Ln(real effective } \\
\text { exchange rate) }\end{array}$ & 0.0092 & -0.1397 & 1.0000 & & & & & \\
\hline P-value & 0.8083 & 0.0000 & & & & & & \\
\hline $\begin{array}{l}\text { Grwth. } \\
\text { infl. diff. over US. } \\
\text { (1 yr.) }\end{array}$ & -0.1248 & 0.1192 & -0.1663 & 1.0000 & & & & \\
\hline P-value & 0.0050 & 0.0011 & 0.0000 & & & & & \\
\hline $\begin{array}{l}\text { Grwth. } \\
\text { In GDP } \\
\text { (1 yr.) }\end{array}$ & 0.0211 & -0.0232 & -0.0331 & -0.1343 & 1.0000 & & & \\
\hline P-value & 0.6025 & 0.5166 & 0.3404 & 0.0013 & & & & \\
\hline $\begin{array}{l}\text { Vlty. } \\
\text { in stk. } \\
\text { market } \\
\text { (1 yr.) }\end{array}$ & -0.1234 & 0.1095 & -0.1522 & 0.5334 & -0.1285 & 1.0000 & & \\
\hline P-value & 0.0018 & 0.0013 & 0.0000 & 0.0000 & 0.0004 & & & \\
\hline $\begin{array}{l}\text { Grwth. } \\
\text { in stk. } \\
\text { market } \\
\text { ( } 6 \text { month) }\end{array}$ & 0.1869 & -0.0403 & 0.1243 & -0.2274 & 0.1532 & -0.1716 & 1.0000 & \\
\hline P-value & 0.0000 & 0.2621 & 0.0003 & 0.0000 & 0.0000 & 0.0000 & & \\
\hline $\begin{array}{l}\text { Grwth. } \\
\text { in M0 } \\
\text { over } \\
\text { reserves }\end{array}$ & -0.1056 & 0.1966 & -0.1698 & 0.5569 & -0.2156 & 0.6752 & -0.2772 & 1.0000 \\
\hline P-value & 0.0061 & 0.0000 & 0.0000 & 0.0000 & 0.0000 & 0.0000 & 0.0000 & \\
\hline
\end{tabular}

Note: Bold indicates correlation of significant at less than $1 \%$. Private capital inflows are highly correlated with key variables as outlined in the theoretical motivation.

${ }^{7}$ Results of stationarity tests on transformed variables available from authors upon request. Natural log of Real Effective Exchange Rate Index is marginally I(1). 